\title{
Phylogeny and taxonomy of Synechococcus-like cyanobacteria
}

\author{
Jiří KomÁREK ${ }^{1,2}$, Jeffrey R. JOHANSEN ${ }^{2,3}$, Jan ŠMARDA ${ }^{4}$ \& Otakar STRUneckÝ ${ }^{5}$
}

\author{
${ }^{1}$ Institute of Botany, Czech Academy of Sciences, Centre for Phycology, Dukelská 135, CZ-37901 Třebon̆ \\ ${ }^{2}$ University of South Bohemia, Faculty of Science, Na Zlaté Stoce 1, CZ-37005 České Budějovice, Czech \\ Republic; e-mail: jiri.komarek@ibot.cas.cz \\ ${ }^{3}$ John Carroll University, Department of Biology, University Heights, Ohio 44118, USA \\ ${ }^{4}$ Masaryk University, Faculty of Medicine, Department of Biology, Kamenice 5, 62500, Brno-Bohunice, Czech \\ Republic \\ ${ }^{5}$ University of South Bohemia in České Budějovice, Faculty of Fisheries and Protection of Waters, CENAKVA, \\ Institute of Aquaculture and Protection of Waters, Na Sádkách 1780, 37005 České Budějovice, Czech Republic
}

\begin{abstract}
Unicellular cyanobacteria constitute a substantial, ecologically important part of freshwater and marine microflora. Solitary, elongated cyanobacterial cells without apparent slime envelopes and dividing in a single plane perpendicular to the longitudinal axis were traditionally classified into the genus Synechococcus. The type species originates from a freshwater benthic habitat while a number of other Synechococcus-like species were described from diverse environments. Morphologically similar, unicellular populations of "Synechococcus" belong to the most abundant oxygen evolving prokaryotes inhabiting freshwater and oceanic picoplanktic communities. Other species from extreme thermal habitats were described from temperatures over $70{ }^{\circ} \mathrm{C}$. Recent molecular analyses, particularly the $16 \mathrm{~S}$ rRNA gene and other multi-locus gene based phylogenies of Synechococcus-like species reveal the polyphyly and phylogenetic diversity of such simple cyanobacteria emphasizing the necessity of their accurate polyphasic taxonomic re-classification. To better understand the phylogeny of different Synechococcus-like species, we constructed a genome-derived phylogenetic tree using 133 cyanobacterial and eubacterial genomes as well as a 16S rRNA gene phylogenetic tree. Both trees indicate existence of deep splits between individual Synechococcus lineages corresponding with indistinct ecological and cytomorphological differences. The generic units derived from the traditional concept of the genus Synechococcus based on the combined traits and markers must be defined and validly described. The comparative taxonomic classification of phylogenetic clusters corresponding to various morphotypes and genotypes similar to the genus Synechococcus (Cyanobium, Parasynechococcus, Picosynechococcus, Prochlorococcus, Thermosynechococcus, Thermostichus) are discussed in the article.
\end{abstract}

Key words: cyanobacteria, picoplankton, phylogeny, Synechococcus-like genera, taxonomy

\section{INTRODUCTION}

Prokaryotic cyanobacteria are an indispensable component of the Earth's biosphere. The $\sim 3400$ My of their existence provided sufficiently long time for their evolution and diversification (TOMITANI et al. 2006). Today, they play a prominent role among the phototrophic microbial communities in almost all ecosystems. Cyanobacterial picoplankton (solitary cells smaller than 2-3 $\mu \mathrm{m}$ in diameter) inhabits all eutrophic freshwater (KoMÁRKOví 2002a, b; ERNST et al. 2003; GARCIA-Pichel et al. 2003; CALlieri et al. 2012) and marine habitats (PARTENSKY et al. 1999; ZEIDNER et al. 2003; PéreZ \& CARrillo 2005; SiX et al. 2007; Mella-Flores et al. 2012; ScANLAN 2012), where it often dominates in the biomass. The morphologically similar species living in solitary cells or in colonies flourish also in the extreme environments of thermal springs, cold lakes, and deserts of Antarctica (PRISCU et al. 1998; KomáreK 1999; Miller \& CAStenholz 2000; Stibal et al. 2015).

The small unicelled picoplanktic cyanobacteria were traditionally identified as members of the genera Synechocystis SAuvageau (1892) (with spherical cells and division in two subsequent perpendicular planes), or Synechococcus NäGELI (1849) (with elongated oval or rod-like cells with one crosswise, perpendicular division plane). Synechococcus was commonly classified as a rod-like cyanobacterium of benthic freshwater origin in Nägeli's original concept (NäGELI 1849). However, wider ecological range was later attributed to this morphologically simple genus with 
additional species descriptions that were included in numerous monographs (GEITLER 1932; ELENKIN 1938; DesiKaChary 1959; StaRmaCh 1966). Members of the genus Synechococcus were classified from many habitats during most of the $20^{\text {th }}$ century, but the introduction of phylogenetic analyses of DNA sequences into cyanobacterial classification (KOMÁREK 1996; КATOH et al. 2001; Herrero \& Flores 2008; Coutinho et al. 2016a,b; Dvoř́́K 2017), combined with ecological characteristics, enabled the more detailed revision of the diversity within this polyphyletic genus. With polyphasic approach it became also evident that the structure of several traditional cyanobacterial Synechococcus-like taxa is variable and the corresponding units had to be taxonomically revised, including picoplanktic species (KomÁreK et al. 2014).

The minute, very simple, solitary, oceanic cyanobacteria were recognized as belonging to different genera. This set of taxa includes Prochlorococcus (Chisholm et al. 1992) or invalidly described Parasynechococcus (CoutinHo et al. 2016 a,b), which both are genetically related to the freshwater Cyanobium gracile (RIPPKA \& COHEN-BAZIRE 1983). The oceanic members of Parasynechococcus (Synechococcus marinus) and Prochlorococcus are very abundant small coccoid cyanobacteria, both in numbers of individual cells and amount of biomass in planktic communities (PArtensky et al. 1999; PAlenik et al. 2003; Six et al. 2007; Flombaum et al. 2013; DvořÁK et al. 2014a, 2017). Several of these populations have already been described in detail by numerous authors, particularly their metabolic and ecophysiological functions (Rabouille et al. 2007; Hess 2008; Swingley et al. 2008; Wiethaus et al. 2010; BragG 2011; Hughes et al. 2011; MAZARD et al. 2012; SCANLAN 2012; WARD et al. 2012; DvořÁK et al. 2014a, MENA et al. 2016) as well as their genomic characteristics (CoutinHo et al. 2016a,b; DvořÁK 2017).

Synechococcus-like populations were described also as intracellular symbionts (HINDÁK 2013) and 16S rRNA gene and multilocus phylogenies revealed that Synechococcus-like cyanobacteria from hot-springs occur in different phylogenetic clades (e.g. Hess 2008; SWINGLeY et al. 2008; SCHIRRMEISTER et al. 2013; DvořÁK et al. 2014a,b; DvořÁK 2017; MAREš et al. 2019). The thermophilic genus Thermosynechococcus KATOH et al. (2001, nom. inval.), was distinguished from the typical, traditional Synechococcus mainly by ecophysiological and biochemical features (КАтOH et al. 2001), because all strains and species were known to thrive in thermal waters at high temperatures, possibly up to $70{ }^{\circ} \mathrm{C}$. KaTOH et al. (2001) proposed the name "Thermosynechococcus", but they did not describe the genus validly according to either the bacteriological or the botanical codes of nomenclature (ICNP and ICN, respectively). Other challenging thermophilic "Synechococcus"species originate from a hot spring in Yellowstone National Park, USA (CoPELAND
1936; BHAYA et al. 2007). Several strains currently recognized as "Synechococcus" (e.g. JA-33Ab and JA$23 \mathrm{Ba}$ ) and found at sites with temperatures possibly up to $\sim 70^{\circ} \mathrm{C}$ formed a separate clade in overall cyanobacterial phylogeny (e.g., Miller \& CASTEnholz 2000; SCHIRrmeister et al. 2013; SHIH et al. 2013) and were found related to the Bulgarian strain RUP-VU-1 (STRUNECKÝ et al. 2019).

We have applied, therefore, the polyphasic approach (KoMÁREK \& ANAGNOSTIDIs 1998) for evaluation of the traditional genus Synechococcus sensu lato in this paper. We propose the introductory taxonomic revision and classification of the phylogenetically separate clades as various genera, which can be delimited by a combination of phylogenetic, cytomorphological and ecological markers. We honor those who recognized the clades as separate by using their proposed names and describe new taxa. They will be validly described in this paper under the rules of the ICN. The review of corrected genera is presented in a new proposed classification and discussed in the context of the higher cyanobacterial taxa.

\section{Material ANd Methods}

This paper is based on the study of natural populations respecting the data of previous authors, together with molecular evaluation of numerous isolated strains.

rRNA operon sequencing and phylogenetic analyses. Total genomic DNA was isolated following the modified xanthogenate-SDS buffer extraction protocol with addition of $3 \%$ polyvinylpolypyrrolidone (PVPP) and PEG- $\mathrm{MgCl}_{2}$ precipitation (YILMAZ et al. 2009). A section of the rRNA operon containing the partial 16S rRNA gene and the 16S-23S intergeneric spacer (ITS) was amplified using the primers 359F (NüBEL et al. 1997) and 23S30R (WilmotTE et al. 1993) and a PCR protocol as previously described (MAREš et al. 2013a). Sequencing was performed commercially at Macrogen (Amsterdam, Netherlands) using primers 359F, 23S30R, 1492R, and 810R (BoHUNickÁ et al. 2015). The newly acquired sequences were deposited to NCBI GenBank database under accession numbers MG207959 - MG207960. Forty-four sequences of Synechococcus like cyanobacteria were used for 16S rRNA gene phylogeny. One hundred and seventy-six sequences of cyanobacterial strains outside of the Synechococcus group were added as outgroup taxa for inferring congruent phylogeny as used elsewhere (MAREš et al. 2013a; BoHUNiCKÁ et al. 2015), and the tree was rooted with a representative of Candidatus Melainabacter, the heterotrophic prokaryotic group sister to Cyanobacteria. Sequences were aligned in MAFFT (www.mafft.cbrc.jp) (КАTOH \& STANDLEY 2013) and visually checked in BioEdit 7.0.1 (HaLl 1999).

Bayesian inference (BI) and maximum likelihood (ML) analyses were performed using partial 16S rRNA gene sequences containing a maximum of 1195 characters including nucleotides and indels. Bayesian inference was conducted with MrBayes XSDE V3.2.6 (RoNQuIST et al. 2012) through the CIPRES Science Gateway, applying the GTR+G+I model of nucleotide substitutions, the model indicated as "best" 
model in jModeltest2, also run on the CIPRES Science Gateway. A total of 84 million generations were run. The BI analysis had an estimated sample size (ESS) exceeding 5000 for all parameters (average ESS ranging 5104- 52,570), well above the average of 200 typically accepted as sufficient by phylogenetists (DRUMMOND et al. 2006). The final average standard deviation of split frequencies was $<0.01$. The potential scale reduction factor (PSRF) value for all the estimated parameters in the $\mathrm{BI}$ analysis was 1.00 , indicating that convergence of the MCMC chains was statistically achieved (Gelman \& RUBIN 1992). The ML analysis with rapid bootstrapping was conducted using RAxML-HPC v.8 on XSDE V8.2.10 (Stamatakis 2014), also through the CIPRES Science Gateway, applying the GTR+G+ I model of nucleotide substitutions, with 1000 bootstrap iterations. Bootstrap values for the ML analysis were mapped on to the $\mathrm{BI}$ analysis tree, the phylogeny figured in this publication.

A data set comprehensively covering the complete genomes of cyanobacteria was generated using publicly available genomes from NCBI (ftp://ftp.ncbi.nih.gov/genomes/Bacteria/). A representative set of 117 cyanobacterial genomes supplemented with 8 outgroup bacterial genomes were used for analyses (Figs 1, 2). Data for multi-locus alignment were mined from a custom BLAST database compiled from the 125 genomes. Protein homologs were harvested by TBLASTN searches with an E-value of $1 \mathrm{e}-10$ performed using BLAST+2.2.28 (САмACHO et al., 2009). Synechococcus lividus PCC 6715 (NZ_CP01809) was selected as a reference organism due to its well-annotated genome and intermediate phylogenetic position among cyanobacteria. Amino acid sequences of all of its annotated proteins were BLASTed against the constructed BLAST database. The obtained 2548 sets of amino acid sequences were aligned and reordered using MAFFT with - localpair - reorder - maxiterate 1000 settings (KaTOH \& STANDLEY 2013). Whenever multiple BLAST hits for a single locus were retrieved from a particular genome, only the most similar hit was kept for subsequent analysis. Obtained alignments were further filtered so that only those containing more than 120 cyanobacterial sequences were kept for phylogenetic analysis. The resulting 260 alignments were considered to represent ubiquitous housekeeping loci and they were concatenated providing a 313,388 amino acid alignment. Custom PERL scripts were applied for the BLAST hit filtering and the concatenation of alignments. The validity of the 260 selected protein alignments was tested using OD-seq (JeHL et al. 2015) and Guidance v. 2.02 (Sela et al. 2015) detecting no sequence outliers. All positions in the alignment with less than $80 \%$ site coverage were eliminated, providing a total of 156,767 sites in the final dataset. The tree inference was performed using the RAxML-HPC v. 8 on XSDE V8.2.10 with rapid bootstrapping and with NJ under JTT model and 500 bootstrap (BP) repetitions (due to exceptional time requirements for analysis of such a long alignment) in MEGA 10.0.4 (KumAR et al. 2018).

Morphological and ultrastructural observations. The morphology of 9 strains traditionally classified to Synechococcus were particularly studied. Strains were observed by light microscopy; the observations were repeated through all stages of the batch cultures using an Olympus BX 51 optical microscope equipped with Nomarski DIC optics and an Olympus DP71 digital camera. Extracellular polysaccharides (EPS) in the cultured strains were visualized by adding a drop of shellac-based drawing ink (Koh-i-noor, Czech Republic). Cultured strains were prepared for transmission electron microscopy (TEM) observation.

Living cells from liquid samples (semicultures) were prepared by fixation in glutaraldehyde and osmium tetroxide (KeLlenberger et al. 1958) for 3 hours at $4{ }^{\circ} \mathrm{C}$. Glutaraldehyde $(3 \% ; \mathrm{w} / \mathrm{v})$ was applied in a $100 \mathrm{mM}$ cacodylate buffer, $\mathrm{pH} 7.3$. The cells were postfixed in $1 \%(\mathrm{w} / \mathrm{v})$ osmium tetroxide in the same buffer for 2 hours at $4{ }^{\circ} \mathrm{C}$. Following fixation, cells were washed with the buffer overnight at $4{ }^{\circ} \mathrm{C}$. Thereafter, they were instilled in $1.3 \%$ agar and dehydrated by a series of ethanol concentrations increasing from $70 \%$ to $99.9 \%$ (20 min each) and, thereafter, by pure acetone. Cells were then infiltrated with Durcupan epoxide resin and, in this condition, encapsulated and polymerized using UV light at $4{ }^{\circ} \mathrm{C}$ for 3 days. Ultrathin $(50-60 \mathrm{~nm})$ sections were cut using a Leica EM UC6 ultramicrotome. Sections placed on supporting grids were contrasted by $2.5 \%$ $(\mathrm{w} / \mathrm{v})$ uranyl acetate and Reynolds solution $(3 \%$, w/v, lead citrate) for $6 \mathrm{~min}$. Sections were observed and photographed in an FEI Morgagni 268D digital transmission electron microscope. Osmium fixation was started by application of $1 \%$ $(\mathrm{w} / \mathrm{v})$ osmium tetroxide in $0.7 \%(\mathrm{w} / \mathrm{v})$ veronal-acetate buffer, $\mathrm{pH}$ 6.5, with traces of sodium chloride and calcium chloride. All preparation procedures and photographic documentation following the preparation techniques were the same as the glutaraldehyde fixation.

\section{Results AND Discussion}

The polyphyletic genus Synechococcus was divided into distinct, genetically and taxonomically separated lineages (genera) based on phylogenetic analyses (Figs $1,2)$. The $16 \mathrm{~S}$ rRNA gene phylogeny includes more sequences due to their greater availability in GenBank (www.ncbi.nlm.nih.gov), however it is congruent with the phylogenetic relationship based on multi locus analysis of 260 concatenated genes. Gloeobacter (RIPPKA et al. in MAREŠ et al. 2013), without intracellular thylakoidal membranes is located morphologically also near this cluster of cyanobacteria, but it differs clearly by phylogenetic position and by cell structure. Synechococcus-like, highly thermophilic Thermostichus gen. nov. (Figs 1,2) is located close to the root of all cyanobacterial lineages, in the position between Gloeobacter and filamentous Pseudanabaena where represents evidently an individual taxonomic unit.

The separate node containing Prochlorococcus, Parasynechococcus (= marine "Synechococcus"), and Cyanobium (type strain) forms a separate cluster (Prochlorococcaceae). This clade is a sister to the clade containing Synechococcus sensu stricto both in the 16S rRNA gene and multilocus analyses (Figs. 1, 2). Morphological characters that are commonly used in the characterization of distinct and delimited morphogenera fail within this clade because the particularly freshwater taxa defined herein are mostly morphologically cryptic.

The thermophilic Thermosynechococcus is more closely related to filamentous Pseudanabaenaceae and 
represents a special family in the $16 \mathrm{~S}$ rRNA gene derived phylogeny (Fig. 1), but it formed a slightly more separated clade in the multi-locus phylogenetic tree (Fig. 2). The last described genus Picosynechococcus is positioned distantly from the previously described genera within the family Aphanothecaceae.

\section{Order Thermostichales, family Thermostichaceae}

Four simple, highly thermophilic strains were located in our phylogenetic evaluation close to Gloeobacter (Fig. 1). They had elongated cells with few (2-3) \pm parietal thylakoids (Fig. 5B). According to the molecular analyses, it is necessary to classify these strains into the new genus Thermostichus, which represents a special unit on the level of a separate family and order (Figs 1, 2, 5B, 6; Tables 1, S1, S2).

The genus Thermostichus represents a distinct cluster with strains JA 33Ab, JA 23Ba and RUP-VU-1. In the phylogenomic tree of WALTER et al. (2017) they designated these strains as Synechococcus yellowstonii/Leptococcus yellowstonii (JA 33Ab) and Synechococcus springii/Leptococcus springii (JA $23 \mathrm{Ba}$ ) without further characteristics. They were also located close to the genus Gloeobacter and distantly from strains of Synechococcus elongatus. However, the generic name "Leptococcus" was proposed only in the text and in Table 1, but not described according to either the botanical or prokaryotic codes of nomenclature, and is consequently an invalid name. The species epithets yellowstonii and springii are likely later synonyms of species described by CoPELAND (1936). This cluster contains the extremely thermophilic strains, growing and surviving in the range of temperatures 23.5-85.2(?) ${ }^{\circ} \mathrm{C}$ and corresponding probably to several species, described by CoPELAND (1936) under the generic name Synechococcus from Yellowstone National Park, USA. The morphological similarity of these thermophilic strains to the genus Synechococcus (COPELAND 1936) and Thermosynechococcus (cf. KATOH et al. 2001) is evident, but they differ genetically (Figs 1 and 2). We propose as type species of this extremely thermophilic cluster the Thermostichus vulcanus. As compared with Thermosynechococcus, the extremely high thermophilic Thermostichus clade (Figs 1,2) is genetically different to such a degree that its separation as a special genus and classification in different families is justified. This whole group is also more or less morphologically uniform and therefore can be defined clearly as a separate genus. Very interesting character occurring in the genus Thermostichus is also the obligatory position of one or groups of cyanophycin granules in terminal parts of cells, which look as dark polar points in elongated cells in optical microscope. The presence of these granules is characteristic for all studied specimens in this simple cyanobacterial order.
Thermostichales Komárek et Strunecký ordo nova Description: Unicellular and colonial cyanobacteria. Cells elongated, without prominent mucilaginous envelopes with few parietal thylakoids. Thermophilic (up to over $80^{\circ} \mathrm{C}$ ).

Thermostichaceae Komárek et Strunecký fam. nov. Description: With characters of the order.

Thermostichus Komárek et Strunecký gen. nov. (Figs 1, 2, 6, Table S1)

Description: Cyanobacterial cells solitary, in irregular agglomerations, or in short, few-celled indistinct rows, narrow, with rounded ends, usually several times longer than wide, straight, strictly cylindrical or slightly curved or arcuated, without prominent slime envelopes. Cell division perpendicular in one plane in subsequent generations, symmetrical or slightly asymmetrical, with daughter cells usually separating soon after division, less frequently forming short rows of a few cells. Cytoplasm sometimes with visible narrowed peripheral chromatoplasma (= few, \pm parietal thylakoids), usually pale or intensely olive-green or blue-green, without aerotopes, usually with solitary granules situated in the terminal parts of cells. - Ecology: Mostly in thermal springs from $20-40{ }^{\circ} \mathrm{C}$ (up to possibly over $80^{\circ} \mathrm{C}$, comp. Copeland 1936 under Synechococcus; other habitats not yet confirmed); in such localities probably a cosmopolitan genus.

Type species: Thermostichus vulcanus (Copeland) Komárek et Strunecký comb. nov. (basionym: Synechococcus vulcanus Copeland, Ann. N. Y. Acad. Sci. 1936: 61, 1936).

Figura typica: figura nostra 6e. Because this established genus is based on Copeland's (1936) characteristics and a holotype was not selected and deposited by the original author, we select a neotype from our available material.

Neotype here designated: CBFS A-092-1, dried material of the strain "Thermostichus vulcanus -Rupite" (RUP-VU-1), deposited in the herbarium collection of the University of South Bohemia.

Etymology: Synechococcus-like cyanobacteria with short cylindrical cells, growing in thermal waters.

This thermophilic genus includes probably other morphospecies, which were, however, not yet confirmed genetically (cf. Figs 5B, 6, Table S1):

- Thermostichus amphigranulatus (Copeland) Komárek et Strunecký comb. nov. (Basionym: Synechococcus elongatus var. amphigranulatus Copeland, Ann. N. Y. Acad. Sci. 1936: 59, 1936);

- Thermostichus arcuatus (Copeland) Komárek et Strunecký comb. nov. (Basionym: Synechococcus arcuatus Copeland, Ann. N. Y. Acad. Sci. 1936: 63, 1936);

- Thermostichus bigranulatus (Skuja) Komárek et 
Strunecký comb. nov. (Basionym: Synechococcus bigranulatus Skuja, Fedde Repert. Sp. Nov. 31: 7, 1933); - Thermostichus lividus (Copeland) Komárek et Strunecký comb. nov. (Basionym: Synechococcus lividus Copeland, Ann. N. Y. Acad. Sci. 1936: 56, 1936);

- Thermostichus praelongus (Emoto et Yoneda) Komárek et Strunecký comb. nov. (Basionym: Synechococcus praelongus Emoto et Yoneda, Ecol. Rev. 66: 267, 1940);

- Thermostichus sublividus (Emoto et Yoneda) Komárek et Strunecký comb. nov. (Basionym: Synechococcus sublividus Emoto et Yoneda, Jap. J. Bot. 17: 704-720, 1941);

- Thermostichus sulphuricus (Dor) Komárek et Strunecký comb. nov. (Basionym: Synechococcus sulphuricus Dor, Sea Fish Res. St. Haifa 48: 12-13, 1967);

- Thermostichus vescus (Copeland) Komárek et Strunecký comb. nov. (Basionym: Synechococcus vescus Copeland, Ann. N. Y. Acad. Sci. 1936: 55, 1936); - Thermostichus viridissimus (Copeland) Komárek et Strunecký comb. nov. (Basionym: Synechococcus viridissimus Copeland, Ann. N. Y. Acad. Sci. 1936: 60, 1936).

Other thermophilic species, which contain prominent polar granules in their cells probably also belong to this genus (Fig. 6). Within the genus Thermostichus possibly a few other endemic taxa will be recognized on the species level, to which belong, e.g., Synechococcus

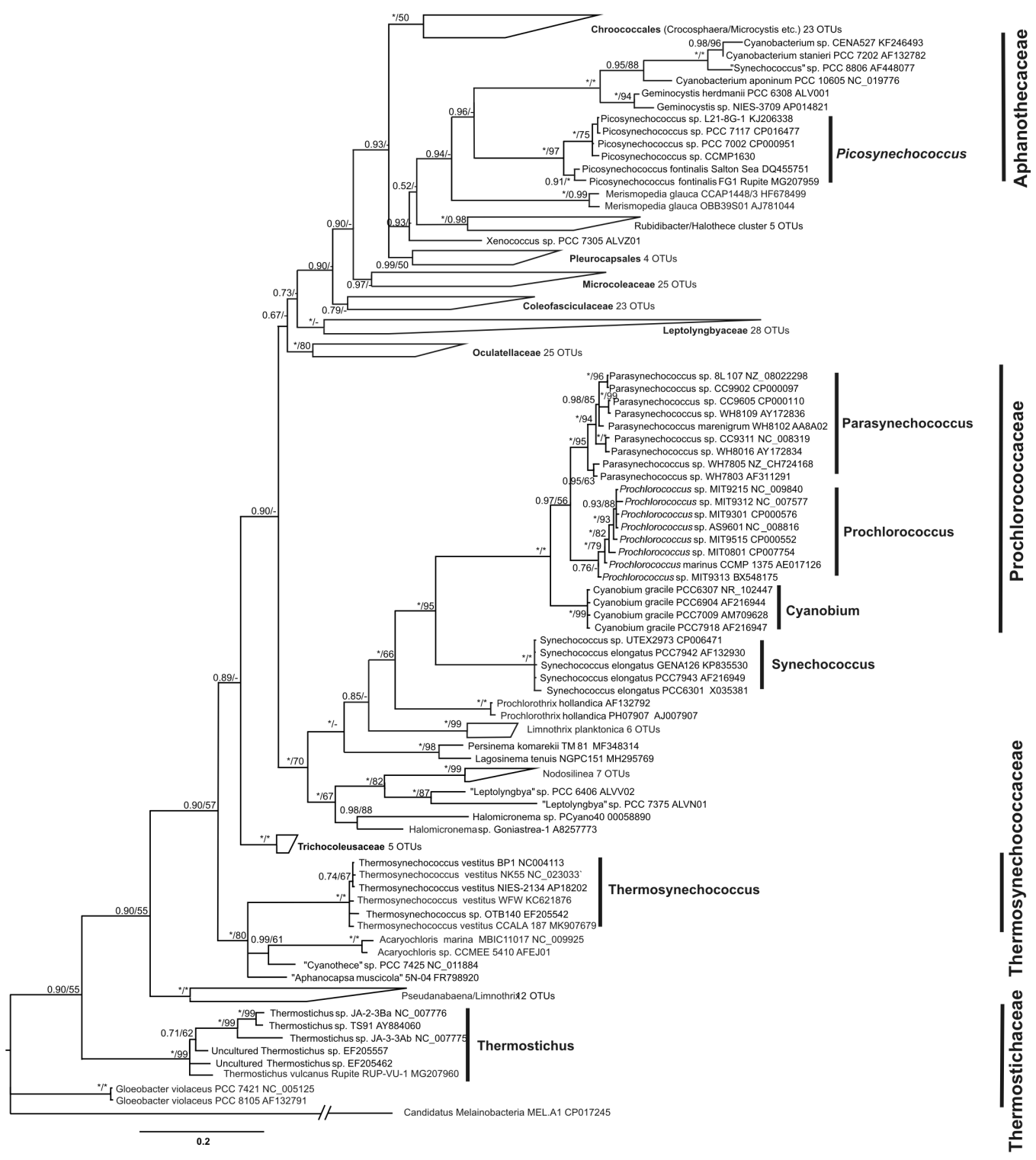

Fig. 1. Bayesian inference with the available "Synechococcus"-like strains, based on 16S rRNA gene sequences derived from our work and NCBI Genbank accessions. Nodes defining clades are noted with these codes. Support values at the nodes represent Bayesian posterior probabilities/ML bootstrap support. The diacritical characters of the families (Aphanothecaceae, Gloeobacteraceae, Prochlorococcaceae, Synechococcaceae, Thermosynechococcaceae) are based also on important qualitative markers, not included in this tree (presence of thylakoids, composition of assimilation pigments). 


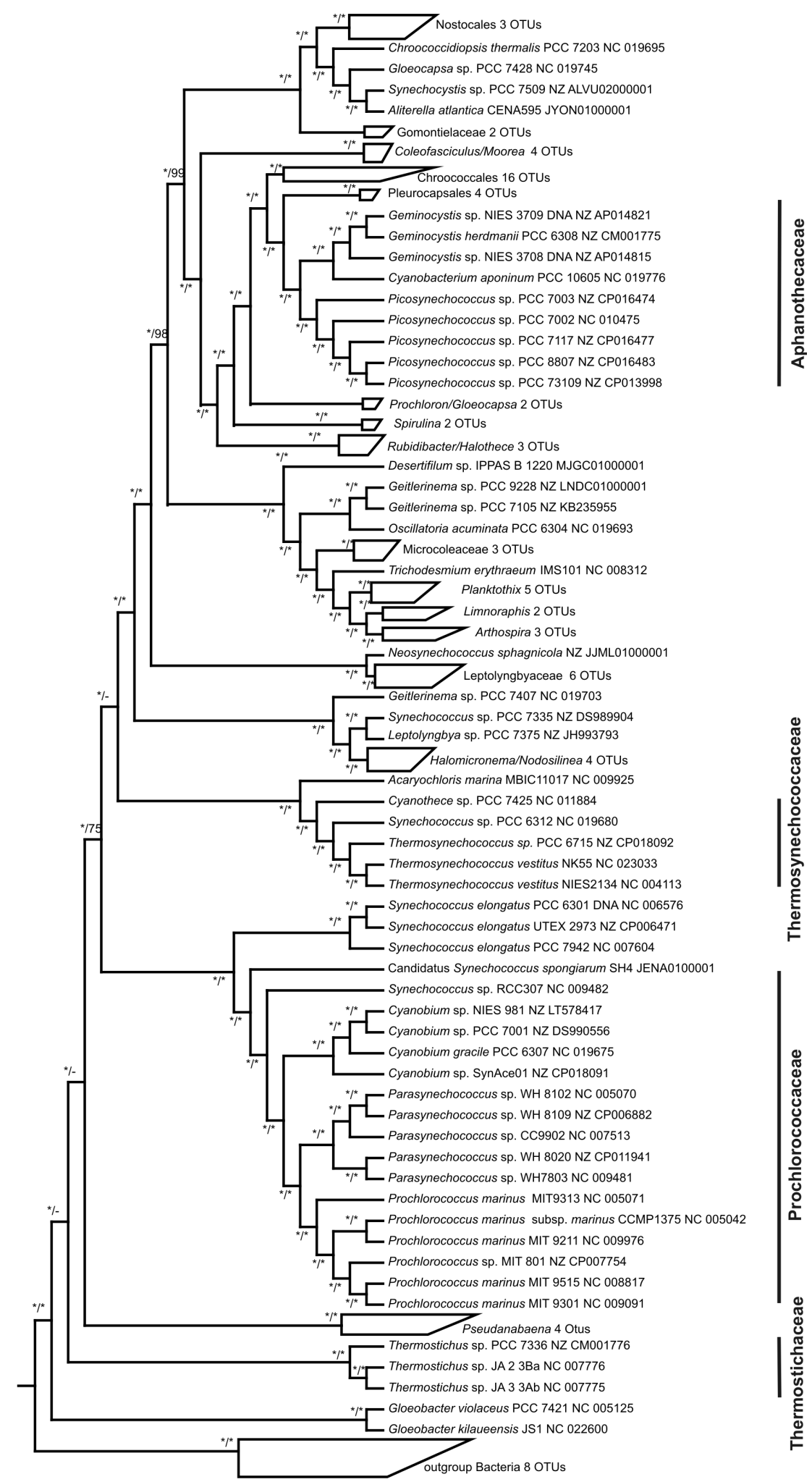

Fig. 2. Multi-locus phylogenetic analysis based on 260 ubiquitous concatenated housekeeping loci. Support values at the nodes represent maximum likelihood and neighbor joining bootstrap support, asterisk indicate the value of 100 .

caldarius OKADA (1939), or a few varieties described within Synechococcus lividus.

\section{Order Synechococcales, family Synechococcaceae} A wide variety of Synechococcus-like strains were identified in the phylogenetic trees (Figs 1, 2, 4A), which are isolated mostly from benthic or planktic habitats of inland freshwaters (comp. e.g. ERNST et al. 2003), or from the thermal springs' habitats. They were characterized by distinctly elongated cells living solitary or in agglomerations. Previously, Synechococcales has been broadly conceived to contain most of the genera with 
Table 1. Short taxonomic review of the simplest phototrophic cyanobacterial orders (partly without thylakoids - Gloeobacterales) and unicellular and filamentous genera with mostly parietal thylakoids in cells (Synechococcales, Pseudanabaenales) (state of 2018). Only genera are included, discussed in the article. The order Chroococcales contains mostly the types with \pm irregularly arranged thylakoids in cells.

Gloeobacterales Gloeobacteraceae Gloeobacter Rippka el al.

Thermostichales Thermostichaceae

\section{Synechococcales}

Cryptogenera

Free unicellular and colonial types; cells divide perpendicular to the long cell axis ex Mareš et al. 2013

Thermostichus Komárek et al. (this paper)

Prochlorococcaceae

Cyanobium Rippka et Cohen-Bazire 1983

Parasynechococcus Coutinho et al. 2016, validation

Prochlorococcus Chisholm et al. 1992

\section{Synechococcaceae (18 genera)}

Synechococcus Nägeli 1849

Merismopediaceae (10 genera)

Prochloraceae (1 genus)

Coelosphaeriaceae (6 genera)

Acaryochloridaceae (1 genus)

Chamaesiphonaceae ( 5 genera)

Pseudanabaenales Thermosynechococcaceae (1 genus)

Thermosynechococcus Katoh et al. 2001, validation

Romeriaceae (4 genera)

Mostly

filamentous types

Chroococcales
Prochlorotrichaceae (4 genera)

Pseudanabaenaceae (11 genera)

Leptolyngbyaceae (23 genera)

Neosynechococcus Dvořák et al. 2014

Heteroleibleiniaceae (3 genera)

Schizothrichaceae (3 genera)

Oculatellaceae (10 genera)

Aphanothecaceae (15 genera)

Picosynechococcus Komárek et al. (this paper)

Cyanobacteriaceae (1 genus)

Chroococcaceae (17 genera)

Microcystaceae (5 genera)

Cyanothrichaceae (1 genus)

Gomphosphaeriaceae (1 genus)

Chroococcaceae (17 genera)

Stichosiphonaceae (1 genus)

Entophysalidaceae (8 genera) 
parietal thylakoids (KoMÁREK et al. 2014) but the later analyses showed the presence of parietal thylakoids through the whole cyanobacterial phylogeny (MAREŠ et al. 2019). However, based on phylogenetic position and distinct ecological constraints of studied strains, it is possible to classify such similar morphotypes in different genera.

The type species of the genus Synechococcus, S. elongatus NäGELI (1849), was described from a mud bed of the Katzensee, a freshwater lake near Zürich in Switzerland $\left(4^{\circ} 25^{\prime} 57^{\prime \prime} \mathrm{N}, 8^{\circ} 29^{\prime} 34^{\prime \prime} \mathrm{E}\right)$, but holotype material is unavailable. The elongated cells are 2.2-4.5 $\mu \mathrm{m}$ long and $1.5 \mu \mathrm{m}$ wide with homogeneous pale cytoplasm. This taxon is commonly known from wet soils, subaerophytic or benthic substrates and from the littoral of freshwater inland water bodies (NäGELI 1849; GeITLER 1932). Due to the impossibility to study the phylogenetic position of the original type material, we have prepared neotype material from the strain that is morphologically, cytologically and ecologically a close match to Nägeli's freshwater epipelic type. The revised genus Synechococcus is in a clade distant in position from other Synechococcus-like strains (Fig. 1).

Synechococcus sp. PCC 6301 was recommended by RIPPKA \& COHEN-BAZIRE (1983) as the reference strain for Synechococcus elongatus, and this recommendation was repeated in Bergey's Manual (Herdman et al. 2001). We accept this proposal due to the close match with Nägeli's original description. The strains corresponding closely to Synechococcus sensu stricto evidently include strains PCC 6301, PCC 7942, PCC 7943, UTEX 2973, and CENA 126. The traditionally defined species as $S$. mundulus, $S$. nidulans, $S$. rhodobaktron belong very probably also to this genus (Table 1), but require molecular confirmation. All strains included in S. elongatus clade had high genetic identities (>99.9\%). CoutinHo et al. (2016b) published a separated cluster (with support of phylogenetic position), designated by the name Synechococcus elongatus with the strains PCC 6301 and PCC 7942 and a sister clade Synechococcus sp. with seven other strains. The ultrastructure of all other members of the genus Synechococcus has not yet been described in detail, but the position of the thylakoids is not strictly parietal, at least in the type species of $S$. nidulans (see fig. 14a in KoMÁREK \& ANAGNOSTIDIS 1986, that showed rather irregularly organized thylakoids in cells). The list of the common Synechococcus species is included in Table S1.

For Synechococcus elongatus NäGELI (1849) we designate the following neotype: CBFS A-102-1, herbarium material preserved by drying biomass of the reference strain, PCC 6301, deposited in the herbarium collection of the University of South Bohemia. Synechococcus elongatus is a freshwater species, periphytic or living on wet soil or mud. PCC 6301 was collected from Waller Creek, Austin, Texas, isolated 1st January 1952. The reference strain Synechococcus elongatus PCC 6301. Additional strains belonging to this species are PCC 7942, PCC 7943, UTEX 2973 and CENA 126.

Order Synechococcales, family Prochlorococcaceae A distinct clade, which contains coccoid genera Prochlorococcus, Parasynechococcus and Cyanobium, represents an isolated cluster (family Prochlorococcaceae; Figs 1, 2, Table 1) with solitary, slightly elongated cells. This group of three genera is phylogenetically separated from other coccoid and filamentous cyanobacterial taxa (including Gloeobacteraceae and Synechococcaceae) based on the phylogeny constructed from 260 concatenated genes (Fig. 2) and must be described as a special family of Synechococcales.

\section{Prochlorococcaceae Komárek et Strunecký fam. nov.}

Description: Unicellular photosynthetic prokaryotes with elongated cells and with 1-4 parietally arranged thylakoids, without gelatinous envelopes. Reproduction by binary fission of cells, perpendicular to the long axis of the cell. At present this family comprises the genera Prochlorococcus, Parasynechococcus and Cyanobium, which differ mainly by phylogenetic markers, by modifications in arrangement of thylakoids in cells and partly by ecology (marine vs. freshwater ecosystems). Type genus: Prochlorococcus.

\section{Prochlorococcus Chisholm, Frankel, Goericke, Olson, Palenik, Waterbury, West-Johnsrud et Zettler gen. nov.}

Description: Oxygenic photoautotrophs possessing divinyl chlorophylls-a and -b as their principal photosynthetic pigments. Cells lacking mucilage, spherical to rod shaped just prior to division, cells individual or in pairs, dividing by transverse binary fission, with peripheral photosynthetic thylakoids closely appressed to one another.

Ecology: mostly marine, planktic species.

Type species: Prochlorococcus marinus.

Etymology: Latin Pro=before, chlorococcus $=$ green coccoid, named for the presence of chlorophyll-b, and idea that this taxon could be the predecessor of chloroplasts in green algae.

Prochlorococcus marinus Chisholm, Frankel, Goericke, Olson, Palenik, Waterbury, WestJohnsrud et Zettler sp. nov. (CHISHOLM et al. 1988; Chisholm et al. 1992) (Fig. 3B)

Description: Cells 0.6 to $0.8 \mu \mathrm{m}$ in diameter, 1.2 to 1.6 $\mu \mathrm{m}$ in length just prior to division. - Habitat: Open ocean waters in subsurface chlorophyll maximum layer.

Type locality: The reference strains for this species (upon which the holotype is based) were isolated from the Sargasso Sea in May 1988 (2858.9'N, 64²1.5'W). 
A
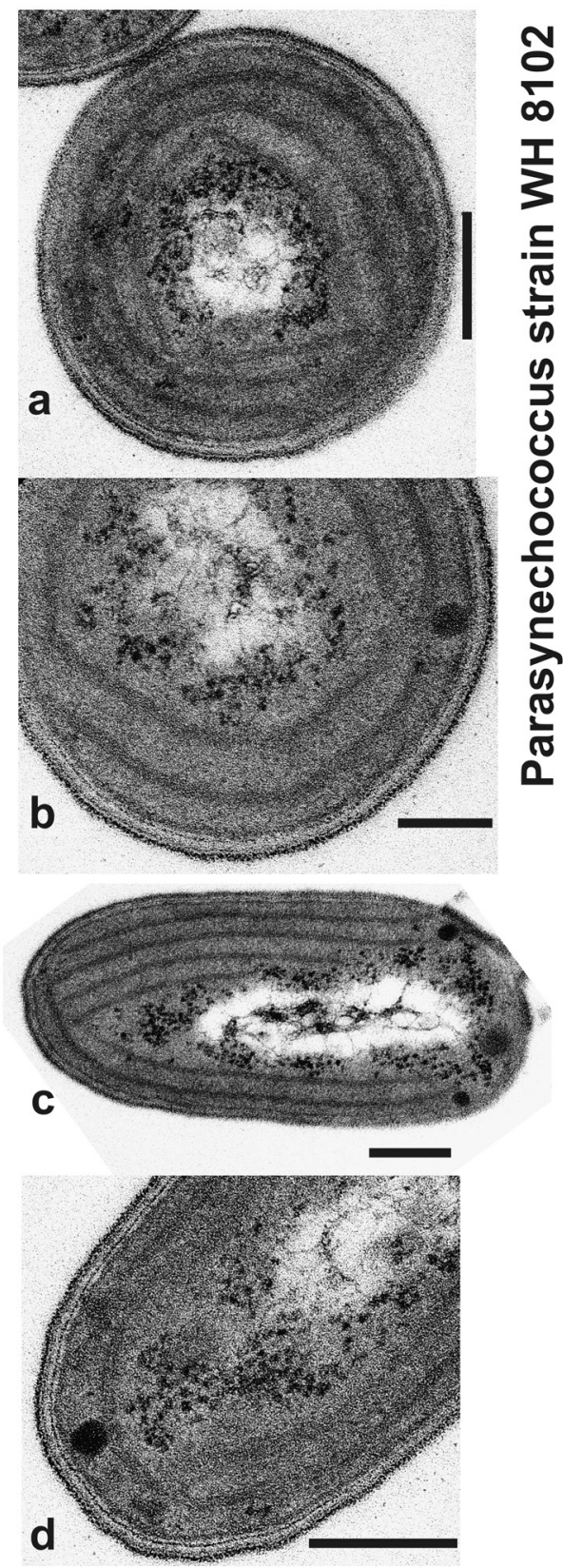

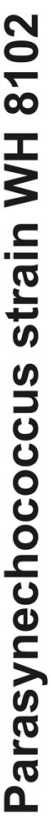

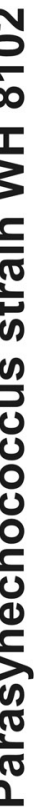
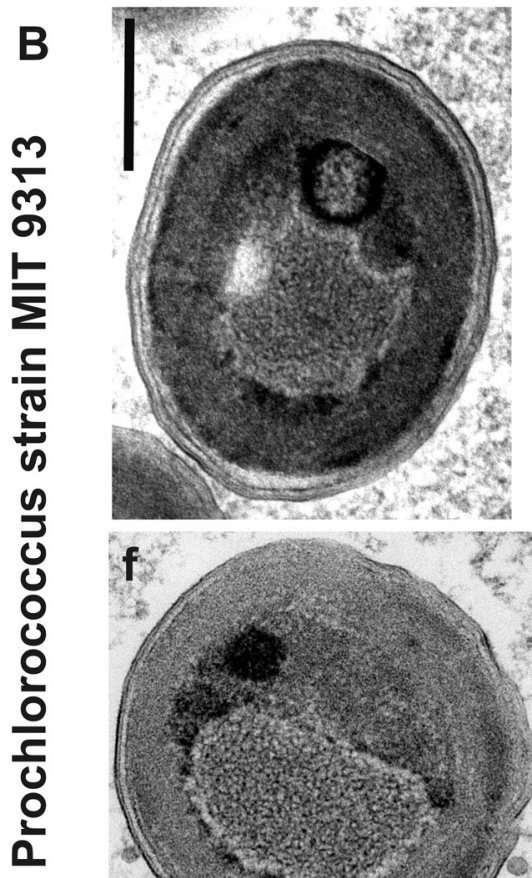

e

Fig. 3. Comparison of the ultrastructure of cells: (A) Parasynechococcus marenigrum (a-d, strain WH 8102); (B) Prochlorococcus marinus (e-h, strain MIT 9313). Scale bars $100 \mathrm{~nm}(\mathrm{~b}), 200 \mathrm{~nm}(\mathrm{a}, \mathrm{c}-\mathrm{h})$.

Holotype here designated: CBFS A-122-1, herbarium material preserved by drying biomass of the strain MIT 9313 is deposited at the Herbarium of the University of South Bohemia.

Additional strains: Prochlorococcus marinus CCMP1375, CCMP-1378.

Etymology: marinus $=$ marine.

Prochlorococcus is a picoplanktic and oceanic autotrophic cyanobacterium originally found by CHISHOLM et al. (1992) from the Sargasso and Mediterranean Seas and cited also in Bergey's Manual. The only described species is Prochlorococcus marinus (in spite of the divarication in phylogenetic schemes, e.g., in Fig. 2, which suggest at least two taxa). Its ecotypes and ecological variability were already characterized by CHARPY \& Blanchot (1999), Furnas \& Crosbie (1999), Hess \& SChÖN (1999), JiaO \& YANG (1999), PARTENSKY et al. (1999), Rocap et al. (1999), and others. The ultrastructure has some specific features in comparison to the morphologically similar Parasynechococcus (Fig. 3A). Strain CCMP-1375 was designated as the type strain by Chisholm et al. (1992), but in her protologue CHISHOLM indicates that neither CCMP-1375 or CCMP-1378 were axenic, meaning they could not serve as types under the ICNP (Rule 18a). Also, the descriptions were not published in IJSEM nor accepted to the list of names in IJSEM, a requirement for 

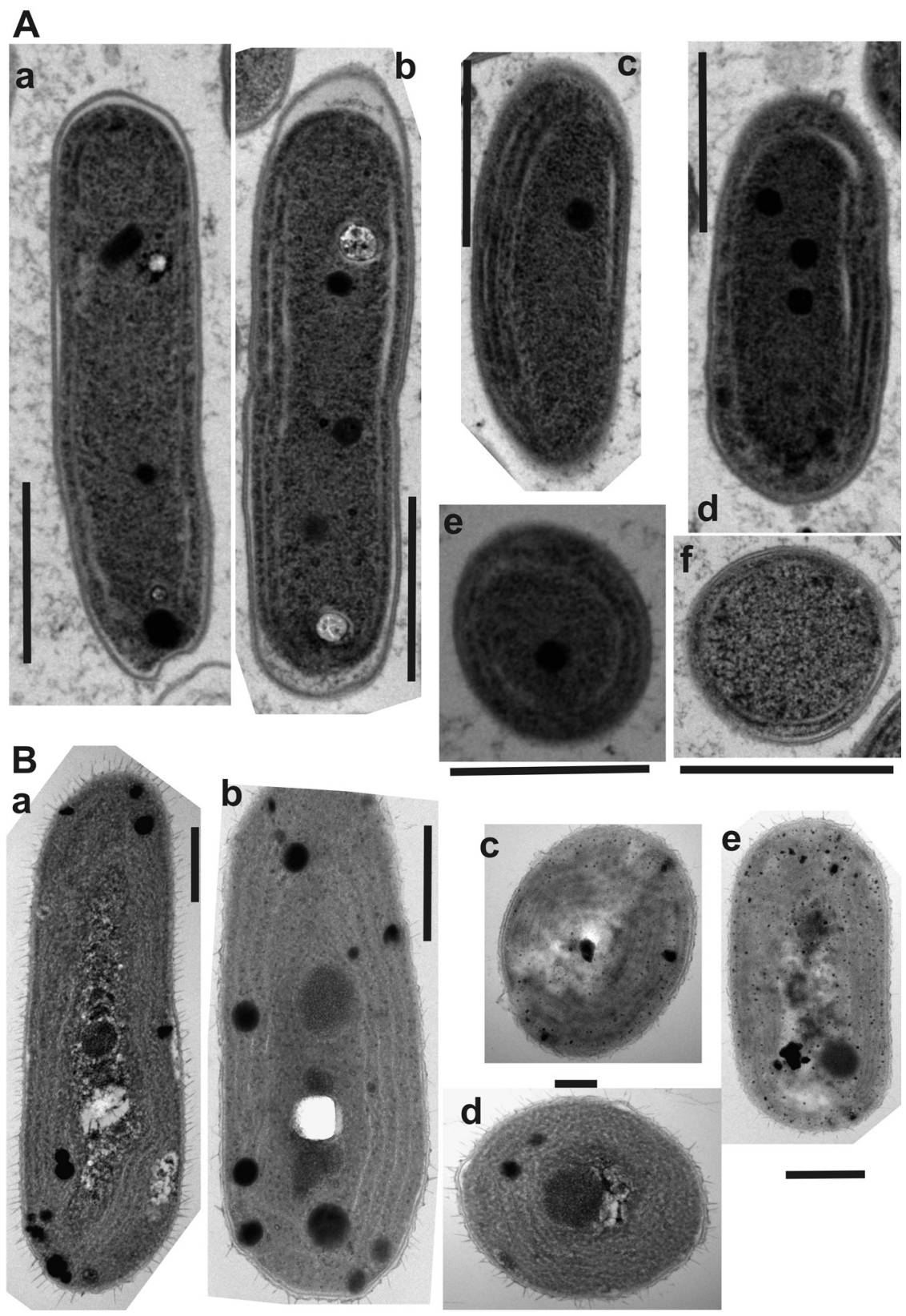

Fig. 4. Ultrastructure of cells: (A) Synechococcus elongatus strains PCC 6301 (CCALA 188), scale bars $1000 \mathrm{~nm}$; (B) Picosynechococcus fontinalis strain FG-1, scale bars $500 \mathrm{~nm}(\mathrm{a}, \mathrm{b}, \mathrm{e}), 200 \mathrm{~nm}(\mathrm{~d})$.

valid publication under the ICNP (Rule 27). A strain cannot serve as holotype under the ICN (Article 8.4), unless it is immobilized (chemical preservation, drying, lyophilisation, or cryopreservation). Their description also violated Article 44.1, which requires a Latin description or diagnosis between December 31, 1958 and December 31, 2011. For these reasons, Prochlorococcus was not validly published under either nomenclatural code. We describe Prochlorococcus as a new genus here so that it will be nomenclaturally valid, serving the requirement in both codes for higher level taxa to be rooted to a genus name. Prochlorococcus was never considered to belong to Synechococcus as its unique pigmentation was recognized soon after it was isolated into culture.
The eight strains of Prochlorococcus in our analysis (Fig. 1) had variable genetic identities (97.8-100\%). According to YARZA et al. (2014), the threshold sequence identity for recognition is $\leq 98.7 \%$, indicating that more than one species could be described even they are morphologically cryptic. Interestingly, the original reference strain, P. marinus CCMP-1375, is below the $98.7 \%$ threshold in comparison to all other strains. Strains MIT 9313 and MIT 0801 are also below the threshold in comparison to the rest of the strains, with the other MIT strains forming a tight group with all being $\geq 99.7 \%$ similar to each other. The TEM images of $P$. marinus CCMP-1375 show 3-5 concentric rings of thylakoids (Chisholm et al. 1988; Chisholm et al. 1992) in comparison to only 2 concentric rings in 
A
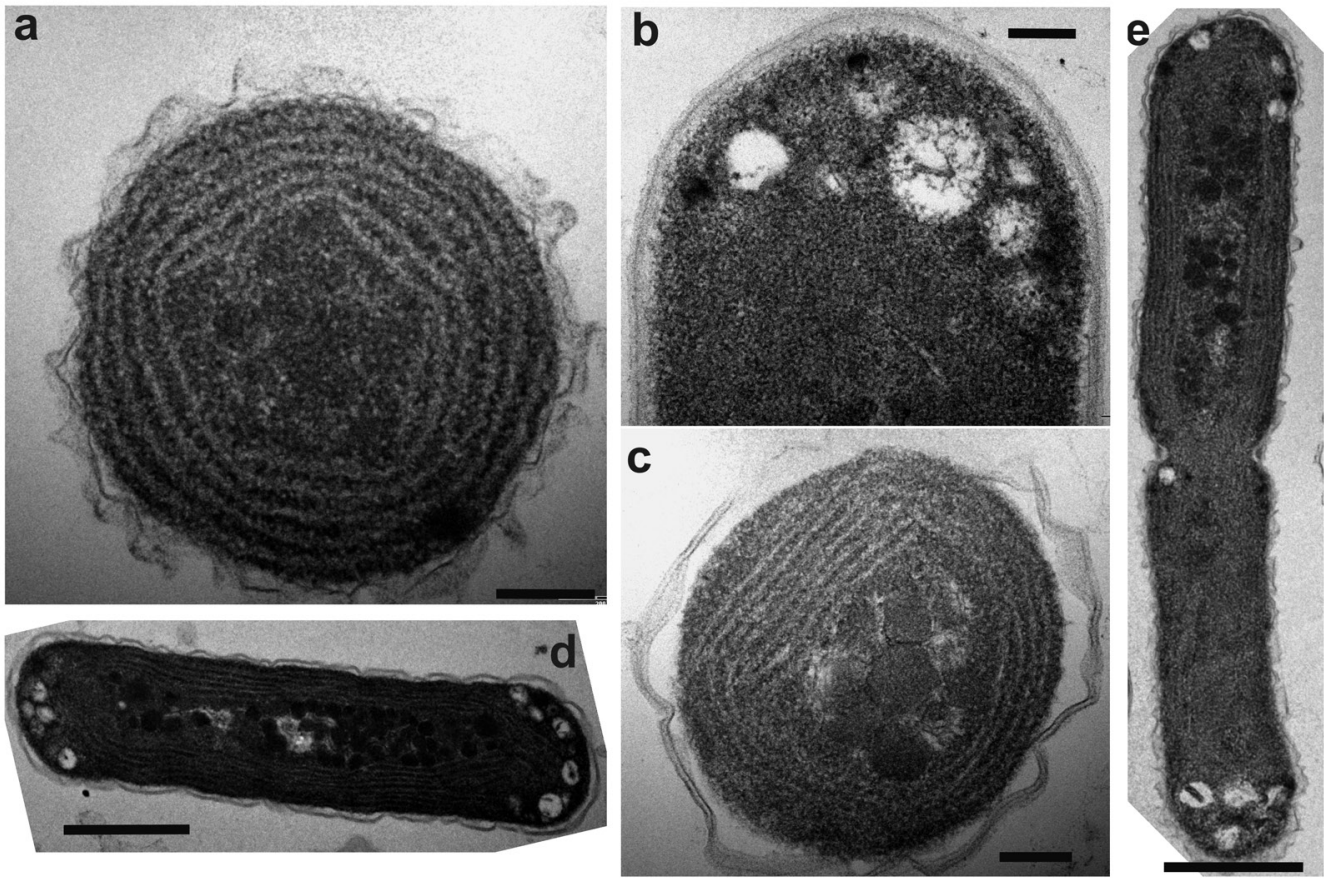

B

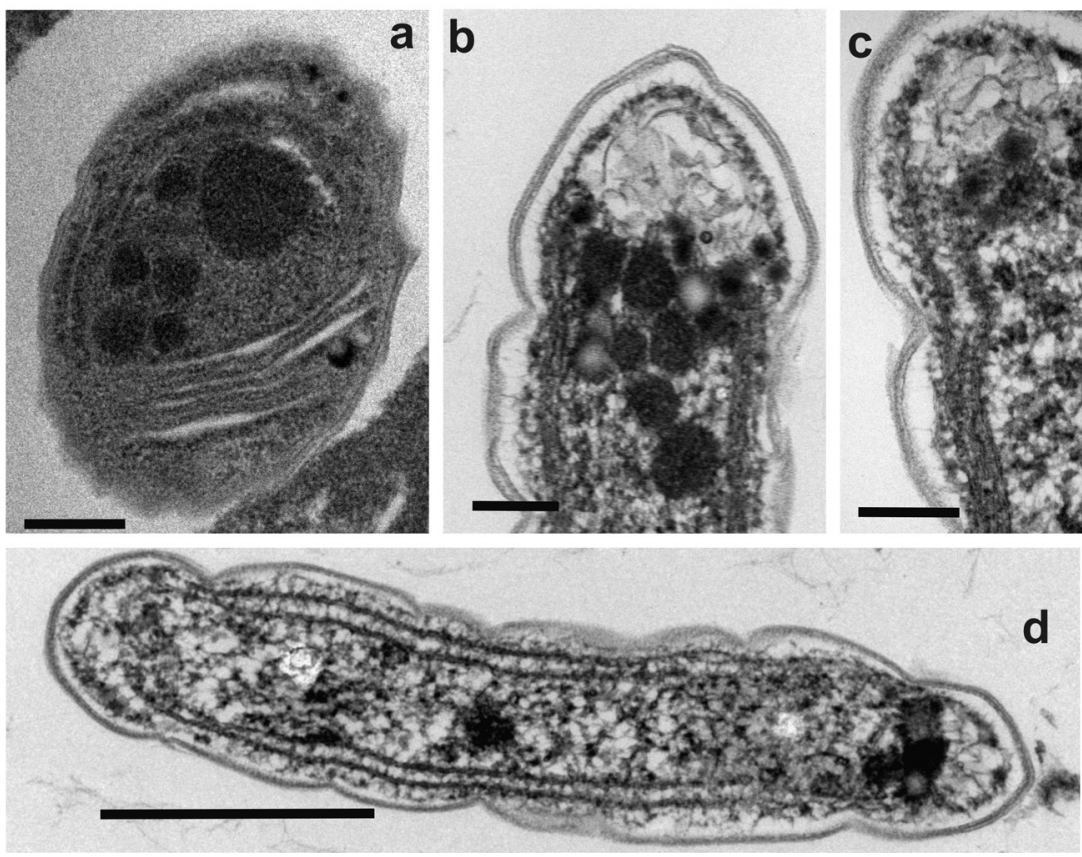

Fig. 5. Ultrastructure of cells: (A) Thermosynechococcus vestitus strain NIES 2133, scale bars 200nm (a,b,c), $1 \mu \mathrm{m}$ (d,e); (B) Thermostichus vulcanus strain RUP-VU-1, scale bars $200 \mathrm{~nm}(\mathrm{a}, \mathrm{b}, \mathrm{c}), 1 \mu \mathrm{m}$ (d).

Prochlorococcus sp. MIT 9313 (Fig. 3B). This coarse analysis would be consistent with the recognition of four species in Prochlorococcus, but defining these species at this point is beyond the scope of this paper.

Parasynechococcus (Coutinho et al. 2016; PeerJ 4:e1522, nomen inval.; Synechococcus sensu auctorum - Partensky et al. 1999; Partensky \& GarCZAREK 2010; SCANLAN 2012; SiX et al. 2007; non
Synechococcus NäGELI 1849) was isolated from marine (oceanic) picoplanktic populations of "Synechococcus" and is different from specimens of freshwater habitats according to molecular analyses (BRAHAMSHA 1999), morphology (they are relatively smaller) and according to details of ultrastructure. These populations must be classified in the taxonomic group together with Prochlorococcus and typical Cyanobium (Figs 1,2).

The genomic phylogenetic and ultrastructural 


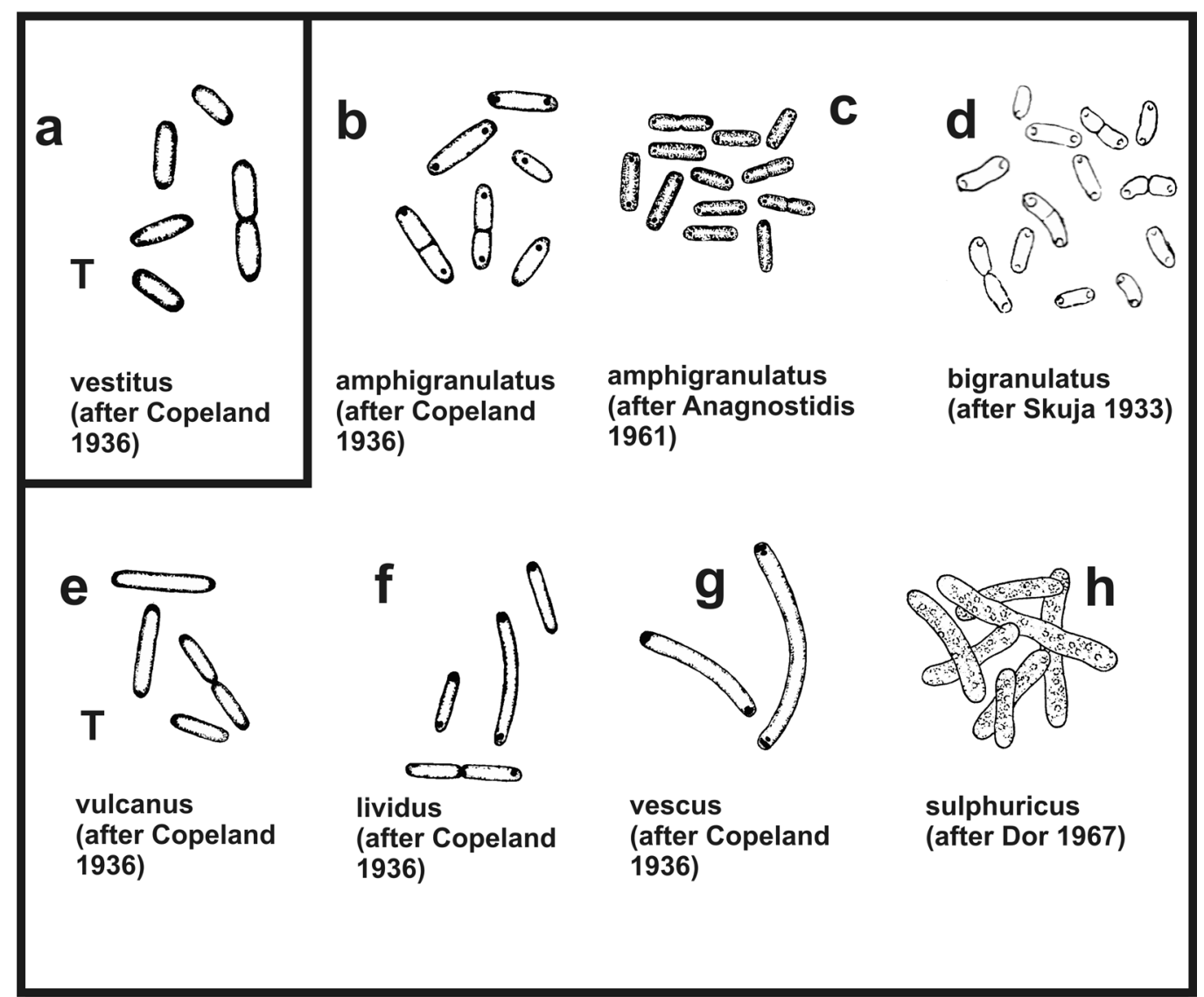

Fig. 6. Morphology of selected characteristic species of extremely thermophilic "Synechococcus"-types with solitary cylindrical cells and \pm with polar granules, which belong mostly to the thermophilic genera Thermosynechococcus ( $\mathrm{a}=T$. vestitus, type of the genus) and Thermostichus (T. vulcanus marked by "T" $-6 \mathrm{e}$ is a type species of the genus). Selected from various authors.

comparison was made between strains of the Prochlorococcus marinus strain MIT9313 and Cyanobium strain WH5701 (Fig 1, Table S2) and the formal descriptions of the separate genera of marine picoplanktic Synechococcus-like populations are therefore necessary. CoutinHo et al. (2016 a, b) published the separate cluster with support of phylogenetic position and used the name Parasynechococcus for oceanic "Synechococcus" populations, but this description is not valid according to both the bacteriological and botanical Codes. Therefore, we validate this genus with the names, proposed by the original authors, who kindly expressed their agreement with this validation.

\section{Parasynechococcus Coutinho, Tschoeke, Thompson} et Thompson gen. nov. (Fig. 3A)

Description: Planktic, marine, solitary picocyanobacterial cells without prominent slime envelopes, subspherical up to slightly elongated and short rod-like, maximally $2.5 \mu \mathrm{m}$ long, with 1-4 parietally arranged thylakoids, without gas vesicles. Reproduction by \pm symmetrical binary fission, perpendicular to the longer axes of the cells, in one division plane in the following generations.

Type species: Parasynechococcus marenigrum Coutinho, Tschoeke, Thompson et Thompson.
Etymology: Gr. Para = similar to; Parasynechococcus = similar to Synechococcus.

Parasynechococcus marenigrum Coutinho, Tschoeke, Thompson et Thompson sp. nov. (Fig. 3A)

Syn.: Synechococcus marinus C.-C. JAO 1948 nom. illeg., non Synechococcus marinus Ercegović 1932.

Description: Cells planktic, marine, solitary, (0.4)0.61.2(2.1) $\mu \mathrm{m}$ long, $0.4-0.8 \mu \mathrm{m}$ wide. Mucilaginous envelopes absent or facultatively forming a very narrow, diffluent and indistinct layer around individual cells. Cytoplasm with (1)2-4 parietal thylakoids, each a little distant from one another, with white bodies between thylakoids in the cells probably corresponding to polyphosphate inclusions, with a few small cyanophycin granules and numerous ribosomes in the centroplasma (Fig. 3A). Cyanophages sometimes seen adsorbed on the cell wall.

Habitat: Marine/oceanic picoplankton from tropical to subpolar zones (type locality: Sargasso Sea). Holotype here designated: CBFS A-094-1, herbarium material preserved by drying biomass of the reference strain, WH 8102, deposited in the herbarium collection of the University of South Bohemia.

Reference strain: Parasynechococcus marenigrum 
WH 8102, previously known as Synechococcus sp. Etymology: referring to the dark water of open ocean in the Sargasso Sea.

The isolated marine (oceanic) picoplanktic populations of "Synechococcus" are different from specimens of freshwater habitats according to molecular analyses (BRAHAMSHA 1999), morphology (they are relatively smaller), and details of ultrastructure. The reference strain upon which our designated holotype is based has been the subject of numerous papers on the ecology and biochemistry of this taxon (Moore et al. 2005; Su et al. 2006; IANCu et al. 2007; Six et al. 2007; TAI \& PALENIK 2009; Tetu et al. 2009; Post et al. 2011, etc.). The genome for WH 8102 was sequenced by PALENIK et al. (2003), and is presented in NCBI as Synechococcus sp. WH 8102 (NC_005070.1).

The cellular structure of oceanic "Synechococcus" (Parasynechococcus) was described by Scanlan (2012). The ultrastructural markers and differences between oceanic Parasynechococcus and Prochlorococcus are in the cell size, cell wall structure, and thylakoid position (Fig. 3). The ecology of the type species Parasynechococcus marenigrum is diagnostic; it forms a more or less homogeneous suspension in upper layers of oceanic water.

WALTER et al. (2017) proposed new generic names (not validly described) for several species of Prochlorococcaceae, but without clear markers and justification (Parasynechococcus: Pseudosynechococcus, Regnicoccus, Magnicoccus, Inmanycoccus; Prochlorococcus: Eurycolium, Prolificoccus, Thaumococcus). The acceptance of these generic names (and many associated species) needs surely more detailed study and formal descriptions according to nomenclatural rules.

CoutinHo et al. (2016b) described 15 species of Parasynechococcus, all of which were invalid due to typification issues under both codes of nomenclature. Their identification is problematic as these species were identified based on genetic data only, with insufficient morphological characterization. They must be confirmed and validated in future studies. Most of the taxa, which they recognized as separate species based on genomic data were above the threshold sequence value $(98.7 \%$ similar) for recognition of separate species. Other species will probably be defined within the genus Parasynechococcus. Synechococcus carcerarius and several described Cyanobium species also possibly belong to this genus.

The genus Cyanobium was proposed in 1983 and the position of the type species (separated from Synechococcus) was confirmed by later phylogenetic as well as our analyses. However, numerous other species were described or combined based only on simple morphology (KOMÁREK \& ANAGNOSTIDIS 1998, KomÁReK 1999) and more than 25 distinguishable taxa are mentioned in the literature. The final position of later Cyanobium-taxa must be confirmed and revised; several of them have a specialized ecology (several marine species belong possibly to the genus Parasynechococcus). This concerns also several taxa defined only morphologically, such as Synechococcus ferrunginosus or $S$. vantieghemii.

\section{Cyanobium Rippka et Cohen-Bazire}

Emended description: Cells solitary, lacking sheaths, without prominent gelatinous envelopes, but producing a thin layer of diffluent mucilage visible with staining by India ink, shortly oval to rod-shaped; cells occurring singly or in pairs, pale blue-green, with homogenous cell content (to $2-4 \mu \mathrm{m}$ long), dividing by perpendicular symmetrical transverse binary fission, with few parietal photosynthetic thylakoids, not closely appressed to one another, with accessory pigments zeaxanthin and $\alpha$-carotene.

Type species: Cyanobium gracile.

\section{Cyanobium gracile Rippka et Cohen-Bazire (Figs} 1,2; Table 1)

Emended description: Cells solitary, without enveloping sheaths, but with thin layer of diffluent mucilage, with homogenous pale blue-green cytoplasm, 0.4-2.4 $\mu \mathrm{m}$ long, $0.2-1.0 \mu \mathrm{m}$ in diameter.

Habitat: $C$. gracile thrive probably in freshwater lakes, but it was also found in brackish waters.

Type locality: lake in Wisconsin, USA, sampled in 1949.

Reference strain: Cyanobium gracile PCC 6307 (=UTEX 1548), additional strains: Cyanobium sp. PCC 6904, PCC 7009, PCC 7918, NIES 981.

Etymology: gracile $=$ thin, slender.

\section{Order Pseudanabaenales, family}

Thermosynechococcaceae

Phylogenetic analyses separated the thermophilic, Synechococcus-like genus Thermosynechococcus (also with rod-like cells) from the Synechococcaceae (Figs 1, 2). The position of this type is closer to the family Pseudanabaenaceae in our 16S rRNA gene phylogeny (Fig. 1), but belongs to a clade isolated from both the Pseudanabaenales and Synechococcales in our multi-locus phylogenetic tree (Fig. 2). We provisionally follow its placement into an order using more common 16S rRNA gene phylogeny, however we expect its possible change after inclusion of additionally sequenced genomes in future. It represents evidently a special family Thermosynechococcaceae, characterised by solitary cells, which form very rarely short filaments (composed from 2-4 connected cells).

\section{Thermosynechococcaceae Komárek, Strunecký et Johansen fam. nov.}

Description: Unicellular photosynthetic prokaryotes with rod-like cells and with 1-4 parietally arranged thylakoids, without or with very slight, colourless and 
diffluent gelatinous envelopes. Reproduction by crosswise, sometimes asymmetrical cell division. Living solitary or in irregular groups. The family is currently comprised of only one genus, Thermosynechococcus gen. nov.

The genus Thermosynechococcus (Figs 1, 2, 5A, 6a; Tables 1, S1, S2) was proposed by КАтоH et al. (2001) and separated from the traditional Synechococcus sensu stricto, mainly according to ecological criteria (КАтOH et al. 2001), because all strains and species were known from thermal waters with higher temperatures. This group was found usually at 20-40(-70) ${ }^{\circ} \mathrm{C}$ and it was characterized also by specific ecophysiological and biochemical features (КАTOH et al. 2001). However, the thermophilic "Synechococcus"-group contains at least two distinct clusters in the phylogenetic schemes, and therefore must be described in two generic taxa, Thermosynechococcus and Thermostichus (see earlier treatment in Thermostichaceae; Figs 1 and 6). The genus Thermosynechococcus was not validly published (no description, no type, etc.) and must be validated (with agreement of original authors).

Thermosynechococcus Katoh, Itoh, Shen et Ikeuchi gen. nov. (Figs 1,6a)

Syn.: Thermosynechococcus Katoh et al. 2001, nom. invalid.

Generic description (validation): Cells solitary or in irregular groups (or strata on the substrate), without prominent slime envelopes, oval, cylindrical, straight or slightly curved, with \pm homogeneous content, rounded or truncated at the ends, (3.0)4.0-17.0(32.0) $\mu \mathrm{m}$ long and 1.1-3.0(4.8) $\mu \mathrm{m}$ wide, with parietal thylakoids. The cell length is variable, sometimes also within the same population. The cells sometimes remain in short, few-celled, filamentous-like formations. Reproduction by binary fission, perpendicular to the long axis of the cells, occasionally in non-morphologically equal parts (asymmetrically).

Habitat: periphytic in thermal localities, benthic, usually in \pm 20 up to $65(-75.8){ }^{\circ} \mathrm{C}$.

Type species: Thermosynechococcus vestitus (syn. “Thermosynechococcus elongatus" sensu КАTOH et al. 2001).

Etymology: Thermo: living in thermal waters.

Thermosynechococcus vestitus (Copeland) Komárek et Strunecký comb. nov.

Basionym: Synechococcus elongatus var. vestitus Copeland, Ann. N.Y. Acad. Sci. 1936: 60, 1936 (Fig 5A)

Neotype here designated: Copeland 1936, p. 59, fig. 24 (under Synechococcus elongatus var. vestitus). Because Copeland (1936) and КАTOH et al. (2001) did not deposit any type material, we designate Copeland's figures (1936, fig. 24) as neotype (created prior to $1^{\text {st }}$ January 2007).

Epitype here designated: CBFS A-120-1, dried material of the strain BP-1 (NIES 2133), deposited in the herbarium collection of the University of South Bohemia.

Reference strain: $T$. vestitus $\mathrm{BP}-1$.

КАтOH et al. (2001) designated the type species as „Thermosynechococcus elongatus“, based on the fact that the strain was originally identified as Synechococcus elongatus, but was found to not belong to that genus based on phylogenetic evidence. This would confuse the typification of the genus, as the type species for Synechococcus cannot serve as a basionym for the type species of Thermosynechococcus. For this reason we do not make a new combination for $S$. elongatus, but rather have chosen Copeland's species $S$. vestitus as the basionym and neotypify and epitypify the species here.

The genus Thermosynechococcus may include (as distinct species) several varieties of various "Synechococcus" taxa from moderately thermophilic and saline habitats, or unsatisfactorily known species not occurring in extremely thermophilic habitats, such as $S$. amethystinus Copeland, S. elongatus f. thermalis Geitler, S. brunneolus Rabenhorst, S. koidzumii Yoneda, S. marinus Jao, S. minutissimus Negoro, $S$. rayssae Dor, or S. sigmoideus (Moore et Carter) Komárek. The position of morphologically similar freshwater and planktic Synechococcus capitatus BaileyWatts et Komárek described from lakes in Scotland is taxonomically still unclear.

\section{Order Chroococcales, family Aphanothecaceae}

Few strains, morphologically similar to the genus Synechococcus, represent an isolated cluster near the family Chroococcaceae. The ultrastructure (irregular position of thylakoids) corresponds also to members of this family. Based on ultrastructural and genetic features this group must be therefore described as a separate genus (Picosynechococcus, Fig. 1). The family Aphanothecaceae belongs into this order by molecular position and ultrastructure, and contains mainly genera with elongated cells.

Picosynechococcus genus novum (not benthic and not oceanic planktic "Synechococcus"- like species) (Figs 1, 2, 4B; Tables S1, S2) has a cryptic character in comparison with other Synechococcus-like genera. It contains several freshwater, but not benthic strains, originally classified (according to simple morphology of unicells) to Synechococcaceae (e.g., PCC 7002, PCC 7117, CCMP 1630, FG-1, and others), but genetically situated in the vicinity of various species from Chroococcales. It must be described taxonomically as a distinct generic entity (Figs 1, 2; Table S2) with characteristic (=type) species, Picosynechococcus fontinalis. Strains from this clade are characterized by solitary, small and slightly elongated cells and prefer (according to known data) a higher content of mineral salts in their environment (possibly occur rarely also in slightly saline waters). The strain PCC 7002 was 
designated by Walter et al. (2017) as a special genus Enugrolinea (and the species E. euryhalinus), but without valid description.

Picosynechococcus Komárek, Johansen et Strunecký gen. nov. (Figs 1, 2, 4B; Tables 1, S1, S2) Description: Cells solitary, without prominent mucilaginous envelopes, slightly elongated and oval, rounded at the ends, sometimes very slightly curved, with homogeneous, blue-green or greenish content, motile, with \pm parietal, a little irregularly organized and waved thylakoids, without gas vesicles. The cells are connected rarely freely in short (few-celled) filamentous formations. Reproduction by cell binary fission in one plane, perpendicular to the longer axis of the cell. Habitat: Planktic and in periphyton in watery localities in mineral springs, sometimes with higher content of salts, rarely also in the littoral of seas.

Type species: Picosynechococcus fontinalis.

Picosynechococcus fontinalis Komárek, Johansen et Strunecký spec. nov. (Figs 1, 2, 4B)

Description: planktic, periphytic, or metaphytic , solitary, slightly oval cyanobacterial cells with few parietal thylakoids and \pm homogeneous content, $1.2-3.0 \times$ $0.8-2.0 \mu \mathrm{m}$.

Locus classicus: Bulgaria, Rupite, in small, freshwater bodies in the area of warm, mineral pools.

Holotype here designated: strain FG-1 (type and reference strain), original dried herbarium specimen, deposited in herbarium collection of the University of South Bohemia, under the designation CBFS A-093-1. Etymology: pico = extremely small Synechococcuslike type from springs.

\section{SUMMARY}

Picocyanobacteria living as solitary cells have increasingly been observed in various planktic habitats often contributing significantly to their primary production appeared in the last few decades, in both freshwaters (KOMÁREK 1996; BECKER et al. 2004; CAllieri et al. 2012) and marine waters (RABOuILle et al. 2007; ZwIRGLMAIER et al. 2008; MARTINY et al. 2009; Flombaum et al. 2013), particularly in tropical ecosystems.

They represent a few diversified groups, and their correct evaluation and taxonomic designation had to be revised and modified in agreement with combined cytomorphological, molecular, ecological, metabolic and physiological studies (polyphasic evaluation). Similar situation exists within morphologically similar thermophilic species which have been placed originally in Synechococcus.

Additional methods including molecular analyses and ecological characteristics were introduced into the taxonomic classification of cyanobacteria during the last few decades of the $20^{\text {th }}$ century (KOMÁREK 1996; Herrero \& Flores 2008; Dvořák 2017; and others). Respecting the phylogenetic and ecological criteria, morpho- and ecotypes corresponding to the traditional taxonomic definition of the genus Synechococcus belong to several different genera (Fig. 2, Table 1) and evidently also to various higher taxonomic categories (families, orders). The recent genetic characterization of many Synechococcus-like species raised the necessity for correcting their taxonomic position. The generic name Synechococcus must be used only in accordance with the type species of this genus (which is the freshwater, benthic type from Switzerland, based on $S$. elongatus) and related taxa. All other, morphologically similar, but genetically (and often also ecologically) distant populations must be separated from this genus (e.g., Neosynechococcus was already described and belongs to the family Leptolyngbyaceae).

The genera Cyanobium, Prochlorococcus and Parasynechococcus form a lineage quite distinct from other cyanobacterial lineages based on multilocus analysis (Figs 1,2). These three similar, simple, unicellular and mostly picoplanktic genera with minute solitary cells, which develop often under oligotrophic to slightly eutrophised conditions in oceans, are here classified as an isolated family of simple cyanobacteria (Prochlorococcaceae, Fig. 1, Table 1).

The specificity of a marine "Synechococcus" was mentioned already by WATERBURY \& RIPPKA (1989), who characterized this cluster by simple solitary picoplanktic, often motile cells. In these types was recognized sometimes reddish cell content and chromatic adaptation (SIX et al. 2007). The fact that marine Prochlorococcus (CHISHOLM et al. 1992), Parasynechococcus (CoutinHo et al. 2016) and freshwater Cyanobium (the original strain) are phylogenetically closely related one to another and separated from the typical Synechococcus, was predicted already by CASTENHOLz (2001) and also confirmed previously by multi-genomic analysis of SCHIRRMEISTER et al. (2011), who designated this group as a separate, extensive phylogenetic cluster. Members of Prochlorococcaceae are some of the most abundant cyanobacteria found on Earth. Marine picocyanobacteria dominate and are well adapted to the spatial, light and trophic conditions of large areas of the seas and oceans (RABOUILLE et al. 2007; ZWIRGLMAIER et al. 2008; Martiny et al. 2009; Flombaum et al. 2013). Due to their importance in oceanic ecosystems, many efforts have been carried out to understand their function and adaptations. Hence, while the taxonomic validity and particularly the morphological generic classification of marine "Synechococcus" was problematic, this name was widely used in the descriptions of almost all marine picocyanobacteria (LINDELL et al. 1999; YIN \& Henley 1999; Castenholz 2001; Herrero \& Flores 2008). However, the ecophysiological and genetic 
markers of "marine Synechococcus" were described also by many other authors (MOORE \& CHISHOLM 1999; PARTENSKy et al. 1999; Rocap et al. 1999; PALENIK et al. 2003; RABOUILLE et al. 2007; Zwirglmaier et al. 2008; Martiny et al. 2009; Mena et al. 2016), who also support the separation of these types from the typical Synechococcus.

In comparison with other cyanobacteria, the picocyanobacterial strains of Prochlorococcus have the shortest cyanobacterial genome with a range from 1.64-2.68 Mbp (Kettler et al. 2007; BiLleR et al. 2014) and an upper limit of $\sim 3 \mathrm{Mb}$ (DuFresne et al. 2003; TING et al. 2009) while other genomes of other sequenced cyanobacteria are slightly larger and span from 4 to $11 \mathrm{Mb}$. Other genera from Prochlorococcaceae have probably more genes in their slightly larger genomes: Parasynechococcus (= marine "Synechococcus": 2.22-2.86 Mbp) and Cyanobium gracile (PCC 6307: 2.83-3.34 Mbp). They also belong to the smallest cyanobacteria in terms of cell size. Minimalization of the genome is considered to be an adaptation of Prochlorococcus to the oligotrophic conditions of the ocean, where this plankter is found (PARTENSKY \& GARCZAREK 2010). Small cell size brings other physical advantages, such as a smaller sedimentation rate and larger surface to volume ratio, both worthwhile properties in aquatic and highly competitive microbial environments. Oceanic Prochlorococcus and Parasynechococcus, specialized for marine oligotrophic environment (SHIBATA et al. 2001; Dufresne et al. 2003; GARCIA-FernANDEZ \& Diez 2004; Ting et al. 2009; RaE et al. 2013) are characterized also by specific metabolic processes and physiological and biochemical modifications (e.g., carbon fixation and nitrogen metabolism pathways). Various other features are outside the main scope of this paper, such as the presence of different type of carboxyzomes than in the other cyanobacteria, different metabolism of amino acids, different membrane ion channels, different ATP synthase etc. (CHISHOLM et al. 1992; Dufresne et al. 2003; ZhANG \& BryANT 2011; Yu et al. 2012; MenA et al. 2016). Several morphologically similar and taxonomically validly described picocyanobacteria from both marine and freshwater habitats, which were earlier included by KomáreK \& Anagnostidis (1998) into to genus Cyanobium (Cyanobium waterburyi, C. oceanicum, C. bacillare, etc.) also belong probably to this group, but their detailed taxonomic (especially molecular) evaluation is still mostly lacking. We consider the genomic phylogeny more reliable than the $16 \mathrm{~S}$ rRNA gene phylogeny (Fig. 1), which places the Prochlorococcaceae next to the Synechococcaceae (Table 1).

The genus Gloeobacter, lacking thylakoids and considered to be the most primitive cyanobacterium due to its cytomorphological simplicity (RIPPKA \& Cohen-BAzIre 1983; MAReš et al. 2013b), is morphologically also similar to Prochlorococcaceae. It can be found also at the base of $16 \mathrm{~S}$ rRNA trees, more or less parallel to the Prochlorococcaceae (Fig. 2), however, the absence of thylakoidal membranes classifies it taxonomically outside of this group. It is interesting that a new discovered, highly thermophilic genus Thermostichus, in cells of which were detected few parietal thylakoidal membranes, belongs genetically to the vicinity of Gloeobacter. However, the phylogenetic and cytomorphological differences between both these genera are so important that Thermostichus must be classified in a specially family and order.

The freshwater genus Picosynechococcus contains also very small planktic picocyanobacteria (Fig. 1), which were often overlooked in floristic studies probably due to small size of solitary living cells and relatively low numbers in small water bodies. It must be compared with populations described as "Synechococcus spp." from large inland lakes (ERNST et al. 2003; BECKER et al. 2004), and this genus occurs also, e.g., in relatively undisturbed mineral and hot springs and pools in Rupite, Bulgaria, where it lives in temperatures between 20 to $40{ }^{\circ} \mathrm{C}$. Ecology and other physiological features of such types should be studied more in the future.

The ecologically interesting thermophilic Synechococcus-like cyanobacteria with cylindrical cells have been divided into several phylogenetic groups (Figs 1,2) and validated. The first problem was that the already defined genus Thermosynechococcus was not validly described in KATOH et al. (2001) and the authors did not define clearly the type species. Moreover, Thermosynechococcus sensu KaTOH et al. (2001), growing in the temperature range $\pm 20(?)-65(75,8){ }^{\circ} \mathrm{C}$ is different phylogenetically from the other extremely high thermophilic types (e.g., strains JA 33Ab and JA $23 \mathrm{Ba}$ ) with long, strictly cylindrical cells growing possibly (according to COPELAND 1936) up to more than in $80{ }^{\circ} \mathrm{C}$ (comp. the genus Thermostichus, Figs 1, 5B, 6). We validate therefore the genus Thermosynechococcus in the sense of KATOH et al. (2011) with necessary selection of the type species, with respect to the insufficient description and typification of the genus in the original paper of KATOH et al. (2001) and describe Thermostichus as a new generic entity. The genus Thermosynechococcus was studied by several authors under "Synechococcus" (e.g., the complete genome structure of the strain BP1 was described by NAKAMURA et al. 2002). The authors of this generic entity (KATOH et al. 2001, p. 600) write that they re-named "Synechococcus vulcanus from Japanese hot springs in Yanomine as Thermosynechococcus vulcanus", but also they mention the "thermophilic cyanobacterium Thermosynechococcus (formerly Synechococcus) elongatus strain BP-1 from a hot spring in Beppu, Japan", and with the species Thermosynechococcus vulcanus and "T. elongatus" sensu Katoh, which belong in separate clades. However, Synechococcus elongatus, as the type species of the genus Synechococcus 
is not thermophilic and "Synechococcus elongatus sensu YAMAOKA et al. (1978), strain BP-1" (and sensu $\mathrm{KATOH}$ et al. 2001) must be classified as a separate species of the genus Thermosynechococcus, different from NÄGELI's (1849) type (cf. Fig. 2), in spite of the similar specific epithet ("elongatus"). We validate therefore the genus Thermosynechococcus in the sense of KATOH et al. 2011 (with his kind agreement) and CoPELAND (1936, under the generic name "Synechococcus"), with necessary selection of a described species for the type (T. vestitus) with respect to the insufficient description and typification of the genus in the original paper of KATOH et al. (2001).

Both thermophilic genera Thermosynechococcus and Thermostichus (phylogenetically different and classified in different orders) belong probably to the phototrophic organisms (cyanobacteria), adapted to the highest possible temperature acceptable for phototrophic life in the biosphere and could be used therefore as convenient ecological models for experimental studies. However, the adaptations and limits to high temperatures must be studied more in detail, both in nature and in culture; it is possible that their metabolism is very different in various populations and strains.

This paper is the next step in the taxonomic characterization and classification of Synechococcuslike cyanobacteria and briefly describes their phylogenetic relations to other cyanobacterial groups. The cyanobacterial genus Synechococcus is morphologically simple, and was thought to be broadly distributed in diverse habitats. Phylogenetic analyses and physiological studies indicate that the genus in the present concept must be actually classified at least in seven different genera with fairly specific ecological requirements. Many of strains that are phylogenetically distinct from Synechococcus have been important models for physiological and biochemical studies. Unfortunately, early attempts at classification were unsuccessful at validly describing these interesting organisms. This manuscript validates these taxa using the names by which they are known in the literature and recognizes earlier authors as the authors of the genera.

\section{ACKNOWLedgement}

This study was conducted with support from grants GA15-00113S, Ministry of Education, Youth and Sports of the Czech Republic, CENAKVA (LM2018099), European Regional Development FundProject (No. CZ.02.1.01/0.0/0.0/16_025/0007370). The ultrathin sections of cells were prepared and the complete electron microscopy preparation and observation were performed in the Faculty of Medicine of Masaryk University in Brno, with technical work by D. Klemová and Ing. L. Ilkovicz. We thank to Prof. Gabrielson for critics and numerous additions to the manuscript, to Dr. K. Edwards for the language correction, to Dr. M. Koblížek, Prof. O. Prášil and Dr. O. Komárek for cultivation and preparation of strains, to Dr. P. Dvořák for several important information and particularly to D. Švehlová for the technical help and preparation of the manuscript.

\section{REFERENCES}

Becker, S.; Singh, A.K.; Postius, C.; Böger, P. \& Ernst, A. (2004): Genetic diversity and distribution of periphytic Synechococcus spp. in biofilms and picoplankton of Lake Constance. - FEMS Microbiol. Ecol. 49:181-190.

Bhaya, D.; Grossman, A. R.; Steunou, A. S.; Khuri, N.; Cohan, F. M.; Hamamura, N.; Melendrez, M.C.; Bateson, M.M.; Ward, D. M. \& Heidelberg, J. F. (2007): Population level functional diversity in a microbial community revealed by comparative genomic and metagenomic analyses. - ISME Journal $1: 703-713$.

Biller, S.J.; Berubem, P.M.; Berta-Thompson, J.W.; Kelly, L.; Roggensack, S.E.; Awad, L.; RoacheJohnson, K.H.; Ding, H.; GiovannONI, S.J.; Rocap, G.; Moore, L. R. \& Chisholm, S.W. (2014): Genomes of diverse isolates of the marine cyanobacterium Prochlorococcus. - Sci. Data 1:1-11.

Bohunická, M.; Mareš, J.; HrouzeK, P.; Urajová, P.; LuKeŠ, M.; ŠMARDA, J.; KoMÁreK, J.; GaYsina, L.A. \& STRUNECKÝ, O. (2015): A combined morphological, ultrastructural, molecular, and biochemical study of the peculiar family Gomontiellaceae (Oscillatoriales) reveals a new cylindrospermopsin-producing clade of cyanobacteria. - J. Phycol. 51:1040-54.

Bragg, J.G. (2011): How Prochlorococcus bacteria use nitrogen sparingly in their proteins. - Mol. Ecol. 20: $27-28$.

BraHAMSHA, B. (1999): Genetic manipulations in Synechococcus spp. of marine cluster A. - In: Charpy, L. \& Larkum, A.W.D. (eds.): Marine cyanobacteria. - Bull. Inst. Oceanogr., Monaco 19: $517-528$

Callieri, C.; Cronberg, G. \& Stockner, J.G. (2012): Freshwater picocyanobacteria: single cells, microcolonies and colonial forms. - In: Whitton, B.A. (ed.): Ecology of Cyanobacteria II. The Diversity in Space and Time. - pp. 229-247, Springer-Science + Business Media BV.

Camacho, C.; Coulouris, G.; Avagyan, V.; Ma, N.; Papadopoulos, J.; Bealer, K. \& Madden, T.L. (2009): BLAST+: architecture and applications. BMC Bioinformatics 10: 421.

Castenholz, R.W. (2001): Oxygenic photosynthetic bacteria. - In: BoONe, D.R.; CASTENHOLZ, R.W. \& GARRITY, G. M. (eds): Bergey's Manual of Systematic Bacteriology ( $2^{\text {nd }}$ edition $) .-$ pp. 473-600, Springer-Verlag New York.

Charpy, L. \& Blanchot, J. (1999): Synechococcus and Prochlorococcus dominance estimated by flow cytometry in Tuamotu Atoll lagoons. - In: CHARPY, L. \& LARKum, A.W.D. (eds): Marine cyanobacteria. - Bull. Inst. Oceanogr., Monaco, 19: 369-376.

Chisholm, S.W.; Olsen, R.J.; Zettler, E.R.; Goericke, R.; Waterbury, J. B. \& Welschmeyer, N. A. (1988): A novel free-living prochlorophyte abundant in the oceanic euphotic zone. - Nature 334: 340-343.

Chisholm, S.W.; Frankel, S.L.; Goericke, R.; Olson, R.J.; Palenik, B.; Waterbury, J.B.; Westjohnsrud, L. \& ZetTler, E.R. (1992): Prochlorococcus-marinus nov. gen. nov. sp. - an oxyphototrophic marine prokaryote containing divinyl chlorophyll-a and chlorophyll-b. - Arch. Microbiol. 157: 297-300.

Copeland, J.J. (1936): Yellowstone thermal Myxophyceae. 
- Ann. New York Acad. Sci. 36: 1-232.

Coutinho, F.; Tschoeke, D.A.; Thompson, F. \& Thompson, C. (2016a): Comparative genomics of Synechococcus and proposal of the new genus Parasynechococcus. PeerJ 4: e1522.

Coutinho, F.; Dutilh, B. E.; Thompson, C.C. \& Thompson, F.L. (2016b): Proposal of fifteen new species of Parasynechococcus based on genomic, physiological and ecological features. - Arch. Microbiol. 198: 973-986.

DesiKachary, T.V. (1959): Cyanophyta. - 686 pp., ICAR Monographs on Algae, New Delhi.

Dor, I. (1967): Algues des sources thermales de Tibériade. Bull. Sea Fish. Res. Sta. Haifa 48: 1-29.

Drummond, A.J.; Ho, S.Y.W.; Philips, M.J. \& Rambaut, A. (2006): Relaxed phylogenetics and dating with confidence. - PLoS Biology 4: e88.

Dufresne, A.; Salanoubat, M.; Partensky, F.; Artiguenave, F.; AXMAnN, I.M.; Barbe, V.; Duprat, S.; GalPerin, M.Y.; Koonin, E.V.; Le Gall, F.; Makarova, K.S.; Ostrowski, M.; Oztas, S.; Robert, C.; Rogozin, I.B.; Scanlan, D.J.; Tandeau de Marsac, N.; Weissenbach, J.; Wincker, P.; Wolf ,Y.I. \& Hess, W.R. (2003): Genome sequence of the cyanobacterium Prochlorococcus marinus SS120, a nearly minimal oxyphototrophic genome. - Proc. Nat. Acad. Sci. USA 100: 10020-10025.

Dvoř́́k, P. (2017): Genome-wideAnalysis of Cyanobacterial Evolution: The Example of Synechococcus. In: Los, D.A. (ed.): Cyanobacterial Omics and Manipulation.- pp. 35-53, Caister Academic Press.

Dvořák, P.; Casamatta, D.A.; PoulíčKová, A.; HašLER, P.; OnDŘeJ, V. \& SANGES, R. (2014a): Synechococcus: 3 billion years of global dominance. - Mol. Ecol. 23: $5538-5551$.

Dvořák, P.; Hindák, F.; Hašler, P.; Hindáková, A. \& PoulíčKová, A. (2014b): Morphological and molecular studies of Neosynechococcus sphagnicola, gen. et sp. nov. (Cyanobacteria, Synechococcales). Phytotaxa 170: 24-34.

ElENKIN, A. A. (1938): Monographia algarum cyanophycearum aquidulcium et terrestrium in finibus USSR inventarum. [Sinezelenye vodorosli SSSR]. - 1908 pp. Izd. AN SSSR, Moskva-Leningrad.

Емото, Y. \& YonedA, Y. (1940): Studies on the thermal flora of Japan VI. Bacteria and algae of the Ibusuki thermal springs. - Ecol. Rev. (Sendai) 6: 257-274. (In Japanese).

Емото, Y. \& YonedA, K. (1941): Bacteria and algae of the thermal springs in Shimane prefecture (II). - Jap. J. Bot. 17: 704-720.

ERCEGOvic, A. (1932): Études écologiques et sociologiques des Cyanophycées lithophytes de la côte Yougoslave de l'Adriatique. - Bull. Internat. Acad. Yougoslave Sci. Arts, Class mat. - nat. 26: 33-56.

Ernst, A.; Becker, S.; Wollenzien, U.I.A. \& Postius, Ch. (2003): Ecosystem-dependent adaptive radiations of picocyanobacteria inferred from $16 \mathrm{~S}$ rRNA and ITS1 sequence analysis. - Microbiology 149: 217-228.

Flombaum, P.; Gallegos, J.L.; Gordillo, R.A.; Rincon, J.; Zabala, L.L.; JiAO, N.; KARL, D.M.; LI, W.K.W.; Lomas, M.W.; Veneziano, D.; Vera, C.S.; VRugt, J.A. \& MartinY, A.C. (2013): Present and future global distributions of the marine Cyanobacteria Prochlorococcus and Synechococcus. - Proc. Nat.
Acad. Sci. USA 110: 9824-9829.

Furnas, M. \& CrosBie, N.D. (1999): In situ growth dynamics of the photosynthetic prokaryotic picoplankters Synechococcus and Prochlorococcus. - In: CHARPY, L. \& LARKum, A.W.D. (eds): Marine cyanobacteria. - Bull. Inst. Oceanogr., Monaco, 19: 387-418.

Garcia-Fernandez, J.M. \& Diez, J. (2004): Adaptive mechanisms of nitrogen and carbon assimilatory pathways in the marine cyanobacteria Prochlorococcus. - Res. Microbiol. 155: 795-802.

Garcia-Pichel, F.; Belnap, J.; Neuer, S. \& Schanz, F. (2003): Estimates of global cyanobacterial biomass and its distribution. - Algological Studies 109: 213-227.

Geitler, L. (1932): Cyanophyceae. - In: Rabenhorst's Kryptogamenflora von Deutschland, Österreich und der Schweiz. - 1196 pp., Akad. Verlagsges., Leipzig.

GeITLER, L. (1935): Kleine Mitteilungen über neue oder wenig bekannte Blaualgen. - Österr. bot. Zeitschr. 84: 287-291.

Gelman, A. \& Rubin, D. B. (1992): Inference from iterative simulation using multiple sequences. - Stat. Sci. 7: $157-511$.

HaLl, T. A. (1999): BioEdit: a user-friendly biological sequence alignment editor and analysis program for windows 95/98/NT. - Nucl. Acids Symp. Ser. 41:95-8.

Herdman, M.; Castenholz, R. W.; Waterbury, J. B. \& RIPPKA, R. (2001): Form-genus XIII. Synechococcus. - In: Boone, D. R.; Castenholz, R. W. \& Garrity, G. M. (eds): Bergey's Manual of Systematic Bacteriology ( $2^{\text {nd }}$ edition $) .-$ pp. 508512, Springer-Verlag, New York.

Herrero, A. \& Flores, E. (2008): The Cyanobacteria. Molecular Biology, Genomics and Evolution. - 484 pp., Caister Academic Press, Norfolk, UK.

Hess, W.R. (2008): Comparative genomics of marine cyanobacteria and their phages. - In: Herrero, A. \& Flores, E. (eds): The Cyanobacteria. Molecular Biology, Genomics and Evolution. - pp. 89-116, Caister Academic Press Norfolk, UK.

Hess, W. R. \& SchöN, A. (1999): Characterization of $r n p B$, the gene encoding the RNA component of RNase P of Prochlorococcus marinus. - In: CHARPY, L. \& LARKum, A.W.D. (eds): Marine cyanobacteria. Bull. Inst. Oceanogr. Monaco 19: 77-82.

Hindák, F. (2013): Endocellular symbiosis in case of cyanelles and algae living in the protoplast of unicellular animals. - Limnol. Zpravod. 7: 7-11.

Hughes, C.; Franklin, D.J. \& Malin, G. (2011): Iodomethane production by two important marine cyanobacteria: Prochlorococcus marinus (CCMP 2389) and Synechococcus sp. (CCMP 2370). Marine Chem. 125: 19-25.

IANCU, C.V.; Ding, H.J.; Morris, D.M.; Dias, D.P.; Gonzales, A.D.; Martino, A. \& Jensen, G. J. (2007): The structure of isolated Synechococcus strain WH8102 carboxysomes as revealed by electron cryotomography. - J. Mol. Biol. 372: 764-773.

JAO, C.-C. (1948): The marine Myxophyceae in the vicinity of Friday Harbor, Washington. - Bot. Bull. Acad. Sinica 2:161-177.

Jehl, P.; Sievers, F. \& Higgins, D. G. (2015): OD-seq: outlier detection in multiple sequence alignment. BMC Bioinformatics 16: 269. 
Jiao, N. \& Yang, Y. (1999): Distribution of Synechococcus, Prochlorococcus, and picoeukaryotes in the East China Sea. - In: Charpy, L. \& LARKum, A.W.D. (eds): Marine cyanobacteria. - Bull. Inst. Oceanogr. Monaco 19: 435-442.

КатоH, H.; Ітон, S.; Shen, J. R. \& Ikeuchi, M. (2001): Functional analysis of psbV and a novel c-type cytochrome gene psbV2 of the thermophilic cyanobacterium Thermosynechococcus elongatus strain $\mathrm{BP}-1$. - Plant Cell Physiol. 42: 599-607.

Katoh, K. \& Standley, D. M. (2013): MAFFT multiple sequence alignment software version 7: improvements in performance and usability. - Mol. Biol. Evol. 30: 772-780.

Kellenberger, E.; Ryter, A. \& Sechaud, J. (1958): Electron microscope study of DNA containing plasms. II. Vegetative and mature phage DNA as compared with normal bacterial nucleoids in different physiological states. - J. Biophys. Biochem. Cytol. 4: 671-678.

Kettller, G.C.; Martiny, A.C.; Huang, K.; Zucker, J.; Coleman, M.L.; Rodrigue, S.; Chen, F.; Lapidus, A.; Ferriera, S.; Johnson, J.; Steglich, C.; Church, G.M.; Richardson, P. \& Chisholm, S.W. (2007): Patterns and implications of gene gain and loss in the evolution of Prochlorococcus. - PLoS Genetics 3: 2512-2528 (e231).

KomÁreK, J. (1996): Towards a combined approach for the taxonomy and species delimitation of picoplanktic cyanoprokaryotes. - Algological Studies 83: 377-401.

KoMÁREK, J. (1999): Intergeneric characters in unicellular cyanobacteria, living in solitary cells. -Algological Studies 94: 195-205.

KomÁreK, J. \& AnAgnostidis, K. (1986): Modern approach to the classification system of cyanophytes $2-$ Chroococcales. - Algological Studies 43:157-226.

KomÁreK, J. \& ANAGnostidis, K. (1998): Cyanoprokaryota 1.Teil: Chroococcales. - In: EtTL, H.; Gärtner, G.; Heynig, H. \& Mollenhauer, D. (eds): Süsswasserflora von Mitteleuropa 19/1. - 548 pp., Gustav Fischer Jena-Stuttgart-Lübeck-Ulm.

KomáreK, J.; KaštovskÝ, J.; Mareš, J. \& Johansen, J.R. (2014): Taxonomic classification of cyanoprokaryotes (cyanobacterial genera) 2014, using a polyphasic approach. - Preslia 86: 295-335.

KomÁReK J.; KopeckÝ J. \& CepÁK V. (1999): Generic characters of the simplest cyanoprokaryotes Cyanobium, Cyanobacterium and Synechococcus. - Cryptogamie/ Algologie 20: 209-222.

Komárková, J. (2002a): Do cyanobacterial picoplankton exist in eutrophic reservoirs? - Proc. Int. Assoc. Theor. Appl. Limnol. 28:497-500.

KomÁrkoví, J. (2002b): Cyanobacterial picoplankton and its colonial formations in two eutrophic canyon reservoirs (Czech Republic). - Arch. Hydrobiol. 154: $605-623$.

Kumar, S.; Stecher, G.; Li, M.; Knyaz, C. \& Tamura, K. (2018): MEGA X: Molecular Evolutionary Genetics Analysis across Computing Platforms. - Mol. Biol. Evol. 35: 1547-1549.

Lindell, D.; Padan, E. \& Post, A. F. (1999): Effect of ammonium on nitrate/nitrite uptake and $n t c A$ expression in Synechococcus sp. strain WH7803. - In: CHARPY, L. \& LARKUM, A.W.D. (eds): Marine cyanobacteria. - Bull. Inst. Oceanogr. Monaco 19: 273-278.
Mai, T.; Johansen, J.R.; Pietrasiak, N.; BohunickÁ, M. \& Martin, M. P. (2018): Revision of the Synechococcales (Cyanobacteria) through recognition of four families including Oculatellaceae fam. nov. and Trichocoleaceae fam. nov. and six new genera containing 14 species. - Phytotaxa 325: 1-59.

Mareš, J.; HrouZeK, P.; KaŇa, R.; Ventura, S.; StruneckÝ, O. \& KomÁreK, J. (2013a): The primitive thylakoidless cyanobacterium Gloeobacter is a common rockdwelling organism. - PloS One 8: e66323.

Mareš, J.; KomÁreK, J.; Compère, P. \& Oren, A. (2013b): Validation of the generic name Gloeobacter Rippka et al. 1974, Cyanophyceae. - Cryptogamie/Algologie 34: 255-262.

Mareš, J.; StruneckÝ, O.; BuČInSKÁ, L. \& Wiedermannová, J. (2019): Evolutionary patterns of thylakoid architecture in cyanobacteria. - Front. Microbiol. 10: 277 (22 pp).

Martiny, A.C.; Kathuria, S. \& Berube, P. M. (2009): Widespread metabolic potential for nitrite and nitrate assimilation among Prochlorococcus ecotypes. Proc. Nat. Acad. Sci. USA 106: 10787-10792.

MaZard, S.; Wilson, W.H. \& SCANLAN, D.J. (2012): Dissecting the physiological response to phosphorus stress in marine Synechococcus isolates (Cyanophyceae)(1). - J. Phycol. 48: 94-105.

Mella-Flores, D.; Six, C.; Ratin, M.; Partensky, F.; Boutte, C.; Le Corguille, G.; Marie, D.; Blot, N.; Gourvil, P.; Kolowrat, Ch. \& GarczareK, L. (2012): Prochlorococcus and Synechococcus have evolved different adaptive mechanisms to cope with light and UV stress. - Front. Microbiol. 3: 1-20.

Mena, C.; Reglero, P.; Ferriol, P.; Torres, A.P.; AparicioGonzález, A.; Balbín, R.; Santiago, R.; Moya, G.; Alemany, F. \& Agawin, N. S. R. (2016): Prokaryotic picoplankton spatial distribution during summer in a hyaline front in the Balearic Sea, Western Mediterranean. - Hydrobiologia 779: 243-57.

Miller, S.R. \& Castenholz, R.W. (2000): Evolution of thermotolerance in hot spring cyanobacteria of the genus Synechococcus. - Appl. Environ. Microbiol. 66: 4222-4229.

Moore, L. R. \& Chisholm, S. W. (1999): Photophysiology of the marine cyanobacterium Prochlorococcus: Ecotypic differences among cultured isolates. Limnol. Oceanogr. 44: 628-638.

Moore, L.R.; Ostrowski, M.; Scanlan, D.J.; Feren, K. \& SwEETSIR, T. (2005): Ecotypic variation in phosphorus acquisition mechanisms within marine picocyanobacteria . - Aquat. Microb. Ecol. 39: 257-269.

NÄGELI, C. (1849): Gattungen einzelliger Algen. - Neue Denkschr. Allg. Schw. Natur.-Ges. 10: 1-139.

Nakamura, Y.; KaneKo, T.; Sato, S.; IKeuchi, M.; Katoh, H.; Sasamoto, S.; Watanabe, A.; Iriguchi, M.; KAWASHIMA, K.; KimURA, T.; KishidA, Y.; KIYOKAWA, C.; Kohara, M.; Matsumoto, M.; Matsuno, A.; NaKaZaKi, N.; Shimpo, S.; Sugimoto, M.; TAKeuchi, C.; Yamada, M. \& Tabata, S. (2002): Complete genome structure of the thermophilic cyanobacterium Thermosynechococcus elongatus BP-1. - DNA Res. 9: 123-130.

NüBel, U.; Garcia-Pichel, F. \& Muyzer, G. (1997): PCR primers to amplify $16 \mathrm{~S}$ rRNA genes from cyanobacteria. - Appl. Env. Microbiol. 63: 3327-3332.

Palenik, B.; Brahamsha, B.; Larimer, F.W.; Land, M.; 
Hauser, L.; Chain, P.; Lamerdin, J.; Regala, W.; Allen, E.E.; McCarren, J.; Paulsen, I.; Dufresne, A.; Partensky, F.; Webb, E.A. \& Waterbury, J. (2003): The genome of a motile marine Synechococcus. Nature 424: 1037-1042.

Partensky, F. \& GarczareK, L. (2010): Prochlorococcus advantages and limits of minimalism. - Ann. Rev. Mar. Sci. 2: 305-331.

Partensky, F.; Hess, W.R. \& Vaulot, D. (1999): Prochlorococcus, a marine photosynthetic prokaryote of global significance. - Microbiol. Mol. Biol. Rev. 63: 106-127.

Pérez, M.C. \& CARrillo, A. (2005): Picocyanobacteria distribution in the Ebro Estuary (Spain). - Acta Bot. Croatica 64: 237-246.

Post, A.F.; Penno, S.; Zandbank, K.; Paytan, A.; Huse, S.M. \& Welch, D.M. (2011): Long term seasonal dynamics of Synechococcus population structure in the Gulf of Aqaba, northern Red Sea. - Front Microbiol. 2: 131 .

Priscu, J.C.; Fritsen, C.H.; Giovannoni, S.J.; Paerl, H.W.; McKaY, C.P.; Doran, P.T.; Gordon, D.A.; LanOIL, B.D. \& PinckneY, J.L. (1998): Perennial Antarctic lake ice: a refuge for cyanobacteria in an extreme environment. - Science 280: 2095-2098.

Rabouille, S.; Edwards, C.A. \& Zehr, J.P. (2007): Modelling the vertical distribution of Prochlorococcus and Synechococcus in the North Pacific Subtropical Ocean. - Environm. Microbiol. 9: 2588-2602.

Rae, B.D.; Long, B.M.; Badger, M.R. \& Price, G.D. (2013): Functions, compositions, and evolution of the two types of carboxysomes: polyhedral microcompartments that facilitate $\mathrm{CO}_{2}$ fixation in cyanobacteria and some proteobacteria. - Microbiol. Mol. Biol. Rev.77: 357-379.

Rippka, R. \& COHEN-BAzire, G. (1983): The Cyanobacteriales: a legitimate order based on the type strain Cyanobacterium stanieri? - Ann. Inst. Pasteur, Microbiol. 134B: 21-36.

Rocap, G.; Moore, L.R. \& Chisholm, S.W. (1999): Molecular phylogeny of Prochlorococcus ecotypes. - In: Charpy, L. \& Larkum, A.W.D. (eds): Marine cyanobacteria. - Bull. Inst. Oceanogr. Monaco 19: 107-116.

Ronquist, F.; Teslenko, M.; Van der Mark, P.; Ayres, D.L.; Darling, A.; Höhna, S.; Larget, B.; LiU, L.; Suchard, M.A. \& Huelsenbeck, J.P. (2012): MrBayes 3.2: Efficient bayesian phylogenetic inference and model choice across a large model space. - Syst. Biol. 61: 539-42.

Sauvageau, C. (1892): Sur les algues d'eau douce recoltées en Algérie pendant le session de la Societé Botanique en 1892. - Bull. Soc. Bot. France 39: 54-78.

SCANlan, D.J. (2012): Marine Picocyanobacteria. - In: Whitton, B.A. (ed.): Ecology of Cyanobacteria II. The Diversity in Space and Time. - pp. 503-533, Springer-Science + Business Media BV.

Schirrmeister, B.E.; Antonelli, A. \& Bagheri, H.C. (2011): The origin of multicellularity in cyanobacteria. - BMC Evol. Biol. 2011: 11-45.

SChirrmeister, B.E.; De Vos, J.M.; Antonelli, A. \& BAGHERI, H. C. (2013): Evolution of multicellularity coincided with increased diversification of cyanobacteria and the great oxidation event. - Proc. Nat. Acad. Sci. 110:1791-1796.
Sela, I.; Ashkenazy, H.; Katoh, K. \& Pupko, T. (2015): GUIDANCE2: accurate detection of unreliable alignment regions accounting for the uncertainty of multiple parameters. - Nucleic Acids Res. 43: W7-W14.

Shibata, M.; Ohkawa, H.; Kaneko, T.; Fukuzawa, H.; Tabata, S.; Kaplan, A. \& Ogawa, T. (2001): Distinct constitutive and low-CO2-induced $\mathrm{CO} 2$ uptake systems in cyanobacteria: genes involved and their phylogenetic relationship with homologous genes in other organisms. - Proc. Nat. Acad. Sci. 98: 11789-11794.

Shih, P.M.; Wu, D.; Latifi, A.; Axen, S.D.; Fewer, D.P.; Talla, E.; Calteau, A.; Cai, F.; Tandeau de Marsac, N.; Rippka, R.; Herdman, M.; Sivonen, K.; Coursin, T.; Laurent, T.; Goodwin, L.; Nolan, M.; Davenport, K.W.; Han, C.S.; Rubin, E.M.; Eisen, J.A.; Woyke, T.; Gugger, M. \& Kerfeld, C.A. (2013): Improving the coverage of the cyanobacterial phylum using diversity-driven genome sequencing. - Proc. Nat. Acad. Sci. 110: 1053-1058.

Six, C.; Finkel, Z.V.; Irwin, A.J. \& CAMPBell, D.A. (2007): Light variability illuminates niche-partitioning among marine picocyanobacteria. - PLoS One 2: e1341.

Skuja, H. (1933): Algen. - In: Bosshard, W. (ed.): Botanische Ergebnisse der Deutschen ZentralasienExpedition 1927-28. - Rep. Nov. Spec. Regni Veget. 31: 4-19.

StAmatakis, A. (2014): RAxML version 8: a tool for phylogenetic analysis and post-analysis of large phylogenies. - Bioinformatics 30: 1312-1213.

Starmach, K. (1966): Cyanophyta - sinice. -808 pp. , Flora Slodkow. Polski, PAN, Panstw. Wyd. Nauk, Krakow.

Stibal, M.; Gözdereliler, E.; Cameron, K.A.; Box, J.E.; Stevens, I.T.; GoKul, J.K.; SChOSTAG, M.; Zarsky, J.D.; EDWARDS, A.; IrVINE-FYNN, T.D.L. \& JACOBSEN, C.S. (2015): Microbial abundance in surface ice on the Greenland Ice Sheet. - Front. Microbiol. 6: 225.

Strunecký, O.; KopejtKa, K.; Goecke, F.; Tomasch, J.; Lukavský, J.; Neori, A.; Kahl, S.; PiePer, D.H.; Pilarski, P.; Kaftan, D. \& KoblížeK, M. (2019): High diversity of thermophilic cyanobacteria in Rupite hot spring identified by microscopy, cultivation, single-cell PCR and amplicon sequencing. Extremophiles 23: 35-48.

Su, Z.; MaO, F.; Dam, P.; Wu, H.; Olman, V.; Paulsen, I.T.; PAleniK, B. \& XU, Y. (2006): Computational inference and experimental validation of the nitrogen assimilation regulatory network in cyanobacterium Synechococcus sp. WH8102. - Nucl. Acids Res. 34: 1050-1065.

Swingley, W.D.; Blankenship, R.E. \& RAYMOND, J. (2008): Insights into cyanobacterial evolution from comparative genomics. - In: Herrero, A. \& Flores, E. (eds): The Cyanobacteria. Molecular Biology, Genomics and Evolution. - pp. 21-43, Caister Academic Press, Norfolk, UK.

TAI, V. \& PALENIK, B. (2009): Temporal variation of Synechococcus clades at a coastal Pacific Ocean monitoring site. - ISME Journal 3: 903-915.

Tetu, S.G.; Brahamsha, B.; Johnson, D.A.; TaI, V.; Phillippy, K.; Palenik, B. \& Paulsen, I. T. (2009): Microarray analysis of phosphate regulation in the marine cyanobacterium Synechococcus sp. WH8102. - ISME Journal 3: 835-849. 
Ting, C.S.; Ramsey, M.E.; Wang, Y.L.; Frost, A.M.; Jun, E. \& Durham, T. (2009): Minimal genomes, maximal productivity: comparative genomics of the photosystem and light-harvesting complexes in the marine cyanobacterium, Prochlorococcus. - Photosyn. Res. 101: 1-19.

Tomitani, A.; Knoll, A.H.; Cavanaugh, C.M. \& Terfumi, O. (2006): The evolutionary diversification of cyanobacteria: molecular-phylogenetic and paleontological perspectives. - Proc. Nat. Acad. Sci. 103: 5442-5447.

Walter, J.M.; Coutinho, F.H.; Dutilh, B.E.; Swings, J.; Thompson, F.L. \& Thompson, C.C. (2017): Ecogenomics and taxonomy of Cyanobacteria Phylum. - Frontiers Microbiol., art. 2132, 18 pp.

Ward, D.M.; Castenholz, R. W. \& Miller, S. R. (2012): Cyanobacteria in Geothermal Habitats - In: Whitton, B.A. (ed.): Ecology of Cyanobacteria II. The Diversity in Space and Time. - pp. 39-63, Springer-Science + Business Media BV.

WATERBURY, J.B. \& RiPPKA, R. (1989): Subsection I. Order Chroococcales Wettstein 1924, emend. Rippka et al., 1979. - In: Staley, J.T.; Bryant, M.P.; Pfennig, N. \& Holt, J.G. (eds): Bergey's Manual of Systematic Bacteriology. - pp. 1728-46, Williams \& Wilkins, London.

Wiethaus, J.; Busch, A.W.; DAmmeyer, T. \& FrankenberGDinkel, N. (2010): Phycobiliproteins in Prochlorococcus marinus: biosynthesis of pigments and their assembly into proteins. - Eur. J. Cell Biol. 89: 1005-1010.

Wilmotte, A.; Van der Auwera, C. \& De Wachter, R. (1993): Structure of the 16S ribosomal RNA of the thermophilic cyanobacteria Chlorogloeopsis HTF (Mastigocladus laminosus NTF) strain PCC 7518 and phylogenetic analysis. - FEBS Letters 317: 96-100.

Yamaoka, T.; Satoh, K. \& Katoh, S. (1978): Photoynthetic activities of a thermophilic blue-green alga. - Plant Cell Physiol. 19: 943-954.

Yarza, P.; Yilmaz, P.; Pruesse, E.; Glöckner, F.O.; Ludwig, W.; Schleifer, K.; Whitman, W.B.; Euzéby, J.; Amann, R. \& Rosselló-Móra, R. (2014): Uniting the classification of cultured and uncultured bacteria and archaea using 16S rRNA gene sequences. - Nature Rev. Microbiol. 12: 635-645.

Yilmaz, M.; PhliPs, E.J. \& Tillett, D. (2009): Improved methods for the isolation of cyanobacterial DNA from environmental samples. - J. Phycol. 45: 517-521.

YIN, Y. \& HeNLEY, W.J. (1999): Iron-limited semicontinuous culture studies of marine Synechococcus. - In: Charpy, L. \& LARKum, A.W.D. (eds): Marine cyanobacteria. - Bull. Inst. Oceanogr. Monaco 19: 365-368.

Yu, T.; LI, J.; YANG, Y.; QI, L.; Chen, B.; ZhaO, F.; BaO, Q. \& WU, J. (2012): Codon usage patterns and adaptive evolution of marine unicellular cyanobacteria Synechococcus and Prochlorococcus. - Mol. Phylogen. Evol. 62: 206-213.

Zeidner, G.; Preston, C.H.M.; Delong, E.F.; Massana, R.; Post, A.F.; Scanlan, D.J. \& BÉJA, O. (2003): Molecular diversity among marine picophytoplankton as revealed by $p s b A$ analyses. - Environm. Microbiol. 5: 212-216.

Zhang, S. \& BRYANT, D.A. (2011): The tricarboxylic acid cycle in cyanobacteria. - Science 334: 1551-1553.

ZWIRglmaier, K.; Jardillier, L.; OSTROWSKI, M.; Mazard, S.; GarczareK, L.; Vaulot, D.; Not, F.; Massana, R.; Ulloa, O. \& Scanlan, D. J. (2008): Global phylogeography of marine Synechococcus and Prochlorococcus reveals a distinct partitioning of lineages among oceanic biomes. - Environm. Microbiol. 10: 147-161.

Supplementary material

The following supplementary material is available for this article:

Table S1. Review of the main described and revised Synechococcus-like cyanobacteria, selected from the literature.

Table S2. Taxonomic position of sequenced synechococcoid strains.

This material is available as part of the online article (http:// fottea.czechphycology.cz/contents)

(C) Czech Phycological Society (2020)

Received March 23, 2020

Accepted June 3, 2020 